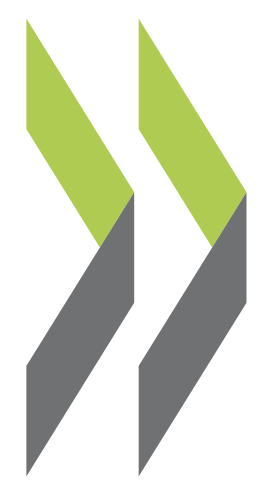

OECD Science, Technology and Industry Working Papers $2005 / 05$

Measuring the Interaction Between Manufacturing and Services 
Organisation de Coopération et de Développement Economiques

DIRECTORATE FOR SCIENCE, TECHNOLOGY AND INDUSTRY

MEASURING THE INTERACTION BETWEEN MANUFACTURING AND SERVICES

STI WORKING PAPER 2005/5

Statistical Analysis of Science, Technology and Industry

Dirk Pilat and Anita Wölfl 


\section{STI Working Paper Series}

The Working Paper series of the OECD Directorate for Science, Technology and Industry is designed to make available to a wider readership selected studies prepared by staff in the Directorate or by outside consultants working on OECD projects. The papers included in the series cover a broad range of issues, of both a technical and policy-analytical nature, in the areas of work of the DSTI. The Working Papers are generally available only in their original language - English or French - with a summary in the other.

Comments on the papers are invited, and should be sent to the Directorate for Science, Technology and Industry, OECD, 2 rue André-Pascal, 75775 Paris Cedex 16, France.

The opinions expressed in these papers are the sole responsibility of the author(s) and do not necessarily reflect those of the OECD or of the governments of its member countries.

\section{http://www.oecd.org/sti/working-papers}


DSTI/DOC(2005)5

\title{
MEASURING THE INTERACTION BETWEEN MANUFACTURING AND SERVICES
}

\author{
Dirk Pilat and Anita Wölfl* \\ OECD and CEPII ${ }^{* *}$
}

\begin{abstract}
This paper examines the interaction between services and manufacturing using several types of data and shows that the distinction between manufacturing and services is blurring. Services make important contributions to production, mainly through their direct contribution to total output and final demand, but to some degree also through their indirect contribution via other industries. However, services are more independent from other industries than the manufacturing sector. Most inputs that are necessary to produce services are derived from the services sector itself. Moreover, their role as providers of intermediate inputs to other industries is not yet as strong as that of the manufacturing sector. The paper also shows that a growing share of workers in the manufacturing sector is engaged in services-related occupations. Using a broad definition of service-related workers, up to $50 \%$ of manufacturing workers are in such occupations. Using firm-level data the paper finds that, despite anecdotal evidence on a growing share of services turnover within the manufacturing sector, manufacturing enterprises in most countries are not very diversified in their constituting establishment, i.e. they do not have many establishments engaged in services production. Canada is a notable exception in this respect. In other countries, it is likely that diversification primarily occurs at the level of the enterprise group. On the other hand, data on products suggest that manufacturing firms and establishments appear to derive a growing share of turnover from services, notably in countries such as Finland and Sweden.
\end{abstract}

* This paper, in particular section 6, draws heavily on tabulations provided by statisticians in several OECD countries, notably Bjarne Moesgaard of Statistics Denmark, Nurmi Satu of Statistics Finland, Desmond Beckstead of Statistics Canada, Hans Björklund of Statistics Sweden and Annabel Montgomery of Statistics New Zealand. The results for Japan draw on a contribution by Kazuyuki Motohashi of the University of Tokyo. The contributions of these statisticians and researchers, and those of their colleagues, are gratefully acknowledged. Any errors in interpreting their findings are our responsibility. This paper benefited from comments by Andrew Wyckoff. Many thanks go to Agnès Cimper for statistical support and to Shuji Tamura for help with the Japanese-language material. This paper reflects the views of the authors and not necessarily those of the OECD or its member countries.

** Anita Wölfl is currently at the Centre d'études prospectives et d'informations internationales (CEPII) but this paper was prepared when she was at the OECD (Economic Analysis and Statistics Division, Directorate for Science, Technology and Industry). 


\title{
MESURE DE L'INTERACTION ENTRE LES INDUSTRIES MANUFACTURIÈRES ET LES SERVICES
}

\author{
Dirk Pilat et Anita Wölfl* \\ OCDE et CEPII ${ }^{* *}$ \\ RÉSUMÉ
}

Cette étude examine l'interaction qui existe entre les services et les industries manufacturières, en s'appuyant sur différents types de données. Elle montre que la distinction entre les industries manufacturières et les services tend à s'estomper. Les services apportent d'importantes contributions à la production, principalement sous forme d'apports directs à la production totale et à la demande finale, mais aussi, dans une certaine mesure, à travers leur contribution indirecte. Toutefois, les services sont plus indépendants des autres industries que ne l'est le secteur manufacturier. La plus grande partie des intrants nécessaires à la production des services procède du secteur des services lui-même. De plus, la place des services dans la fourniture d'intrants intermédiaires à d'autres secteurs n'est pas encore aussi importante que celle de l'industrie manufacturière. Ce travail révèle en outre qu'une proportion croissante des travailleurs du secteur manufacturier est employée à des fonctions liées aux services. Si l'on utilise une définition large des fonctions liées aux services, jusqu'à $50 \%$ des travailleurs du secteur manufacturier relèvent de telles fonctions. En s'appuyant sur des données micro-économiques, ce document montre que, malgré des éléments épars qui sembleraient indiquer qu'une part croissante du chiffre d'affaires du secteur manufacturier correspond à des activités de services, dans la plupart des pays, les entreprises manufacturières restent assez peu diversifiées, ce qui signifie qu'elles ne comptent pas beaucoup d'établissements produisant des services. Le Canada constitue une exception notable à cet égard. Dans d'autres pays, il semble plutôt que la diversification s'opère essentiellement au niveau du groupe. Enfin, les données sur les produits suggèrent que les entreprises et les établissements du secteur manufacturier réalisent une part plus importante de leur chiffre d'affaires grâce aux services, notamment dans des pays comme la Finlande et la Suède.

\footnotetext{
Ce document, en particulier la section 6, s'appuie largement sur des tableaux fournis par des statisticiens de plusieurs pays de l'OCDE, en particulier Bjarne Moesgaard de Statistics Denmark, Nurmi Satu de Statistics Finland, Desmond Beckstead de Statistique Canada, Hans Björklund de Statistics Sweden et Annabel Montgomery de Statistics New Zealand. Pour le Japon, les résultats sont tirés d'une contribution de Kazuyuki Motohashi de l'Université de Tokyo. Nous tenons à exprimer notre gratitude à ces statisticiens et chercheurs et leurs collègues pour leur aide. Nous assumons la responsabilité de toute erreur éventuelle dans l'interprétation de leurs données. Ce travail a en outre bénéficié des commentaires de Andrew Wyckoff. Nos remerciements vont aussi à Agnès Cimper pour le traitement des statistiques et à Shuji Tamura pour son assistance avec les documents écrits en japonais. Ce document reflète les vues des auteurs et pas nécessairement celles de l'OCDE ou de ses pays Membres.

Anita Wölfl travaille actuellement au Centre d'études prospectives et d'informations internationales (CEPII) mais ce document a été préparé alors qu'elle était à l'OCDE (Division des analyses économiques et des statistiques, Direction de la science, de la technologie et de l'industrie).
} 


\section{TABLE OF CONTENTS}

MEASURING THE INTERACTION BETWEEN MANUFACTURING AND SERVICES...................... 6

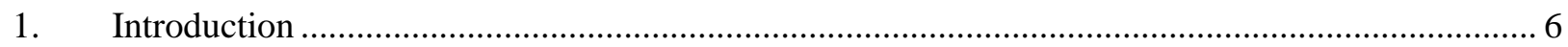

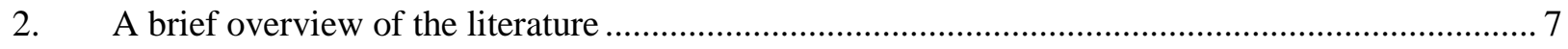

3. Intermediate inputs as an indicator for increased interaction ................................................ 10

4. Inter-sectoral interactions - evidence from input-output tables ............................................... 12

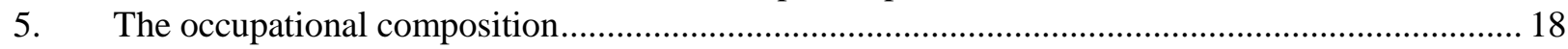

6. Firm-level studies on the manufacturing-services interaction.................................................... 22

6.1. The structure of economies according to enterprise and establishment data .......................... 22

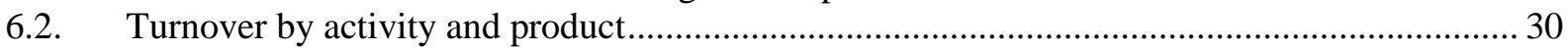

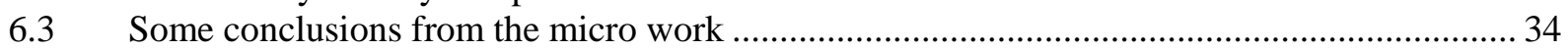

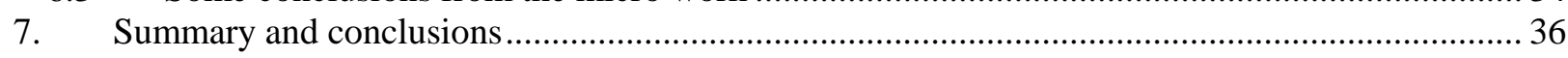

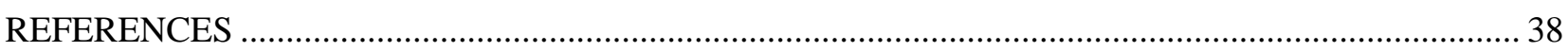

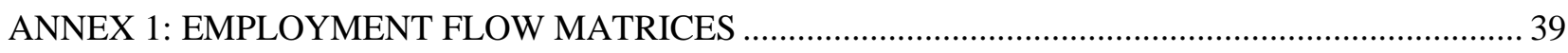

ANNEX 2: THE IMPACT OF CHOICE OF BUSINESS UNITS ON INDUSTRIAL COMPOSITION -

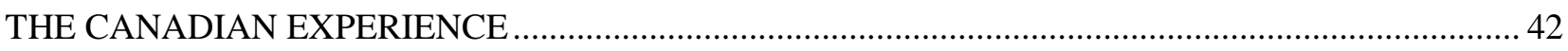

ANNEX 3: METHODOLOGICAL DETAILS FOR FINLAND …......................................................... 44

ANNEX 4: THE INTERACTION OF MANUFACTURING AND SERVICES - THE SWEDISH

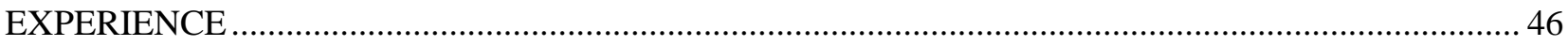

\section{Boxes}

Box 1. Analysing the indirect role of services using input-output tables............................................ 14 


\section{MEASURING THE INTERACTION BETWEEN MANUFACTURING AND SERVICES}

\section{Introduction}

Empirical evidence presented in previous OECD work points to the increasing deindustrialisation of OECD economies (Wölfl, 2003; 2005). Moreover, recent years have shown a growing interdependence between services and manufacturing industries. The share of services activities that is necessary for or complementary to manufacturing production has increased. The production of a car, for instance, now involves a wide range of services activities such as market and technical research, development and design, human resource management and business consulting. Moreover, a car is nowadays often sold in a package that includes financing, which may be provided directly by the car producer or indirectly via subcontracting.

The past two decades have also seen a growing trend towards the outsourcing of business-related services, such as research and development, financing or logistics. Services have been contracted out to specialised service providers, or are provided by a newly created firm or spin-off from a manufacturing firm that can provide the services at lower cost or higher quality. Czarnitzki and Spielkamp (2000) therefore characterise services industries as "bridges for innovation", not only for the services sector, but increasingly also for services-using manufacturing industries. ${ }^{1}$

Most recently the policy debate about the interaction between the services and manufacturing sectors has centred on the outsourcing and off-shoring of services functions. Several OECD countries are concerned that outsourcing of services functions by domestic manufacturing or services firms to other countries, notably to low wage countries, could be at the cost of domestic employment and could lead to increased unemployment. Whether this is the case can not be established a priori, though, and requires detailed analysis of the various direct and indirect effects of outsourcing and off-shoring for OECD countries. The issue is also complicated since the interaction between manufacturing and services goes beyond outsourcing and also comprises other forms of interactions. For example, firms may simply use more intermediate inputs to produce services or goods. If such inputs are sourced from an independent service provider that had not been previously integrated in the final good producing firm or industry, this can not be considered as outsourcing.

To help address these issues, this paper provides new empirical evidence on the interaction between manufacturing and services industries. It first provides a brief overview of theoretical and empirical studies on the interaction between services and manufacturing. This is followed by an empirical analysis of this interaction using four different types of data sources, i.e. data on intermediate inputs from the STAN Database, input-output tables, occupation data and micro-level data. A final section draws some conclusions.

1. Dathe and Schmid (2002) point to the role of regulation in the decision to outsource. If labour markets for services industries are less regulated than those for manufacturing industries, firms may wish to buy services from external providers or outsource as this may circumvent regulations on dismissal or working time. 


\section{A brief overview of the literature}

The interaction between manufacturing and services industries can take various forms; depending on the type of interaction, different conclusions may have to be drawn as regards its implications for productivity growth and employment. In general, four broad categories of interaction between manufacturing and services can be distinguished (Table 1, Antràs and Helpman, 2003; Grossman and Helpman, 2003). ${ }^{2}$ These categories depend on whether the interaction takes place within the country or with other countries; they also depend on which organisational form of domestic or international production is chosen (Antràs and Helpman, 2003; Grossman and Helpman, 2003):

- Vertical integration: A firm can choose to keep production of an intermediate input within its (firm) boundaries, and produce it at home or in a foreign country. When the firm decides to keep it at home, it engages in standard vertical integration. When it decides to produce it within the firm boundaries but abroad, it engages in foreign direct investment (FDI) and in intra-firm trade.

- Buying-in of components, e.g. outsourcing: A firm may choose to buy an input in the home country or in a foreign country. When it buys the input at home, it may do this through domestic outsourcing. When it buys it abroad, such as through foreign outsourcing, it engages in arm's length trade.

Table 1. Broad categories of interactions between industries

\begin{tabular}{|c|c|c|}
\hline \multirow{2}{*}{} & \multicolumn{2}{|c|}{ Organisational form } \\
\hline \multirow{3}{*}{$\begin{array}{c}\text { Standard vertical integration } \\
0\end{array}$} & $\begin{array}{c}\text { Buying-in from a domestic supplier, } \\
\text { (e.g. via outsourcing) } \\
\text { use of domestic intermediate inputs }\end{array}$ \\
\cline { 2 - 3 } & $\begin{array}{r}\text { Vertical integration } \\
\text { FDI and intra-firm trade }\end{array}$ & $\begin{array}{c}\text { Buying in from a foreign supplier, } \\
\text { (e.g. foreign outsourcing) } \\
\text { inter- or intra-industry trade }\end{array}$ \\
\hline
\end{tabular}

Source: based on Antràs and Helpman (2003).

Within this basic setup, Antràs and Helpman (2003) propose that low productivity firms will outsource in the North (which is assumed to be the high wage country) while high productivity firms will outsource in the South (the low wage country). Among the firms that acquire inputs in the same country, high productivity firms will outsource while low productivity firms will "insource" (integrate). Grossman and Helpman (2003) stress the role of transaction costs. They propose that the fraction of firms that outsource, i.e. buy-in intermediate inputs, will be higher the more complete the contracts between the producer of final goods and the supplier of intermediate inputs. Moreover, the fraction that buys from intermediate goods suppliers will be higher the larger the size of the industry. With increasing industry size, the number of final producers will increase and thus the derived demand for specialised services of any intermediate good producer. This will spur entry of intermediate goods producers, which again will create a "thicker" market of suppliers with expertise relatively closely related to the needs of the final goods producers.

In a world of free entry and exit in output and input markets, outsourcing of services functions to specialised service providers will enable final goods producers to produce at lower costs (Fixler and Siegel,

2. These theoretical models equate the buying-in of components and intermediate inputs with outsourcing of related functions. In reality, however, outsourcing is only one example for the buying-in from a domestic or foreign supplier. 


\section{DSTI/DOC(2005)5}

1999). ${ }^{3}$ For these industries, outsourcing will eventually result in a reduction of labour (per firm) and an increase in output due to the cost reduction and entry induced by positive economic profits. This again will increase derived demand for intermediate services providers. As long as labour supply is fixed, an increase in the demand for labour will lead to upward pressures on wages. This may, however, be counteracted by downward pressures on wages if product and input markets are open to entry and exit. ${ }^{4}$ The final effect on productivity growth in services and, thus, indirectly for the total economy, depends on the labour intensity of services production.

From an empirical point of view, matters are more complicated than suggested by these theoretical considerations, however. Both "vertical integration" as well as the "buying in" of components or intermediate inputs may in reality comprise diverse organisational forms and, thus, a broad variety of ways in which firms of different industries interact. As a consequence, the empirical analysis of the interaction between different industries is best carried out by using different methods and levels of analysis, from aggregate analysis of intermediate demand to analysis of firm-level data. This approach is indeed followed within the empirical literature on outsourcing. Existing empirical studies can roughly be grouped according to three questions that are at the same time central questions to analyse the interaction between industries.

First, which particular issue is being analysed? While most empirical studies claim to address the question of outsourcing, the approach and focus taken varies strongly across studies. Kleinert (2003), for instance, analyses whether the observable increase in international trade in intermediate inputs is mainly related to global sourcing, FDI or networks of multinational enterprises (MNE). He finds a significant and strong joint effect of outward and inward FDI stocks on trade in intermediate inputs, and concludes from this that international production plays a role. The impact of outward FDI stocks on imported intermediate inputs is found to be weak, however, although the robustness of the effect increases over time.

Falk and Koebel (2002) analyse the effects of purchased services and imported intermediate materials on the labour demand for different skills. They find that the increasing use of purchased inputs and imported materials reduces the demand for labour for all skill levels, although the effects are not significant. Their evidence points to a substitution over time: given the positive effects of output, capital accumulation and input prices on factor demand, the demand for unskilled labour decreases while the remaining inputs increase over time. Overall, however, output and capital effects are found to be more important as determinants of demand for heterogeneous labour than substitution effects between different types of labour and either purchased services or imported materials. Empirical studies also suggest that if outsourcing occurs, it is often related to the creation of new services rather than to internal restructuring (Dathe and Schmid, 2000). Outsourcing might thus not necessarily be a zero sum game in terms of employment, but could be associated with an increase in total employment.

The second question concerns the level of analysis. Kleinert (2003), Fixler and Siegel (1999), and Falk and Koebel (2002) work on the aggregate and industry level by looking at aggregate data on international trade and FDI, or data on productivity growth, employment and wages per industry. Other studies, such as Egger et al. (2003) work on the firm level. Görzig and Stephan (2002), for instance, use firm-level data from the German cost structure survey to analyse the effects on firm-level performance of three different measures of outsourcing: a) the change in material inputs, which reflects the make-or-buy-decision of a firm, $b$ ) external contract work, as a reflection of subcontracting between firms, and $c$ ) the change in other costs, which includes several external services, such as consultancy and advertising. Their main result is that outsourcing of internal production has a positive impact on firm

3. They do, however, look at only one country and do not distinguish between different forms of international production of intermediate goods.

4. The possibility of taking on part time jobs which are more typical for services as compared to manufacturing firms will also put downward pressure on wages (Fixler and Siegel, 1999). 
performance, as measured by the gross operating surplus, and this effect is relevant both in the short and the long run. In contrast, outsourcing of services seems to be related to contractual difficulties; it shows a negative effect on firm performance in the short run and a positive effect in the long run.

The third question concerns data; notably which data and indicators are the most appropriate. An important consideration is what exactly is being measured by the available data. For instance, whether the buying-in of components and intermediate inputs from a foreign supplier represents intra- or inter-industry trade depends on the level of aggregation and the similarity of the goods and services being considered. Fontagné and Freudenberg (2001) propose different classes of trade in inter- and intra-industry trade. Inter-industry trade in the sense of one-way trade with horizontally differentiated goods represents the traditional view of the international division of labour. In contrast, intra-industry trade in the sense of oneway trade with vertically differentiated products reflects an international separation of the production process. Moreover, intra-industry trade may also take the form of two-way trade, both in similar (final) goods, as well as in vertically differentiated (intermediate) goods. ${ }^{5}$

Problems related to the appropriate data and indicators arise notably with regard to the measurement of "outsourcing". ${ }^{6}$ Feenstra and Hanson (1999), for instance, measure outsourcing as imported intermediate inputs purchased from the same two-digit industry. This indicator will reflect outsourcing in the sense of several theoretical models; it neglects, however, the statistical reality in which outsourced services, i.e. functions that are no longer within the firm group, are not grouped any longer under the same industry as the industry from which it has been outsourced. Kleinert (2003), as another example, measures outsourcing by a company's outward FDI activities. This measure of outsourcing reflects, however, only the production of intermediate inputs within the boundaries of the firm or the firm group; it is not an appropriate measure for outsourcing if this involves the buying in of intermediate inputs from suppliers that are external to the firm or firm group.

The question of the appropriate data is also related to the issue being analysed. Kierkegaard (2004), for instance, mainly uses occupation data to analyse employment patterns in the US job market, focusing on those occupational categories that are threatened by offshore outsourcing. ${ }^{7}$ He finds some indications for a threat of off-shoring for these services occupations. For instance, a vast majority of people working in the "threatened" occupations are in the services sector $(\sim 79 \%)$, and only about $10 \%$ are in the manufacturing sector. Moreover, the decline in employment in threatened categories has occurred disproportionately in the manufacturing sector ( - 25\% over 2000-2002). Several points need to be considered, however. First, the changes in employment in these threatened categories over the period may not necessarily reflect off-shoring, but may also reflect domestic outsourcing of tasks handled by staff in the occupational categories concerned to US-based service-sector companies. Second, general economic developments, as reflected by cyclical developments, competition, or the flexible US labour market in general, may matter more than the incentive to offshore. Third, some of the job losses may not reflect off-shoring, but may reflect technological changes. Fourth, job losses as measured by occupations may say

5. Inter- and intra-industry trade is measured using indicators for product similarity and trade overlap. Traded products are considered to be similar (i.e. horizontally differentiated) when their unit values differ by less than $15 \%$. Trade in an item is considered to be "two-way" when the value of the minority flow represents at least $10 \%$ of the majority flow. Below this level, the minority flow does not represent a structural feature of trade (Fontagné and Freudenberg (2001).

6. See also Stille (2002) and Heshmati (2003).

7. Examples of such threatened occupations are management, business, legal and financial operations, computer and mathematical occupations, architecture and engineering, life, physical and social science occupations, sales and related occupations as well as office and administrative support occupations. See also OECD (2004). 
something about job characteristics, but not necessarily about the person holding the job. Some losses in IT employment, for instance, may be due to the end of a temporary foreign worker's contract.

While the existing empirical studies provide a broad picture of the complexity of the services-manufacturing interaction and some of its effects on productivity growth and employment, using these studies to draw policy conclusions is complicated. In particular, these studies are not comparable as they study a variety of issues for different time periods and for different (typically a small number of) countries. The analysis presented in this paper is an attempt to overcome some of these shortcomings. It is meant to give an overview of the role and forms of interaction between manufacturing and services for OECD countries. It analyses the broad issue of interaction between industries and sectors and how this interaction shows up in the respective data. Where possible it also addresses the issue of outsourcing and its effects on productivity and employment. As suggested by the prior considerations above based on existing theoretical and empirical work, the analysis is best done using several data sources at different levels of aggregation:

1. Structural data, i.e. the OECD STAN Database, can provide a broad picture of the role of intermediate inputs for output growth in manufacturing and services. These data can highlight aggregate patterns of services and manufacturing interaction and their impact on the total economy. This approach is followed in section 3 of the paper.

2. Input-output tables can help to analyse the output and employment flows between industries (Box 1). I-O data allow a distinction of the source of intermediate inputs. Moreover, they allow the analysis of the direct and indirect effects of a demand change in one sector or industry on output and employment in another sector or industry. This approach is followed in section 4 of the paper.

3. Occupation data can help to examine the employment or activity composition within manufacturing and services industries. This approach is followed in section 5 of the paper.

4. Data on trade and foreign affiliates can provide international evidence on the role of the services and manufacturing interaction. To some degree, these data can help distinguish between domestic outsourcing and international sourcing or off-shoring of services functions. Work in this area is currently underway in the OECD's Group of Globalisation Experts and is not reported here.

5. Firm (micro) level data allow an analysis of the employment and sales composition within a firm or enterprise group. To some degree these data can highlight the role of vertical integration as opposed to outsourcing of specific functions to outside providers. This approach is elaborated in section 6 of the paper.

\section{Intermediate inputs as an indicator for increased interaction}

A first way of illustrating the interaction between industries is based on data on intermediate inputs. Figure 1 shows the contribution of intermediate inputs and value added in the growth of gross output for manufacturing and services. In the manufacturing sector, intermediate inputs contributed to between one half and two-thirds of output growth in the 1990s for OECD countries for which data were available. A very strong contribution can be observed for Denmark, France and Italy. Moreover, the contribution of intermediate inputs has increased since the 1980s in most countries, i.e. in Denmark, Finland, France, Norway and the United States. This reflects the increasing trend towards the buying-in of intermediate inputs by manufacturing firms, either through outsourcing of previously integrated functions, or from independent intermediate input providers. 
Figure 1. Contribution of value added and intermediate inputs to growth in gross output, 1980-1990 and 1990-2001*

Average annual contribution in percentage points
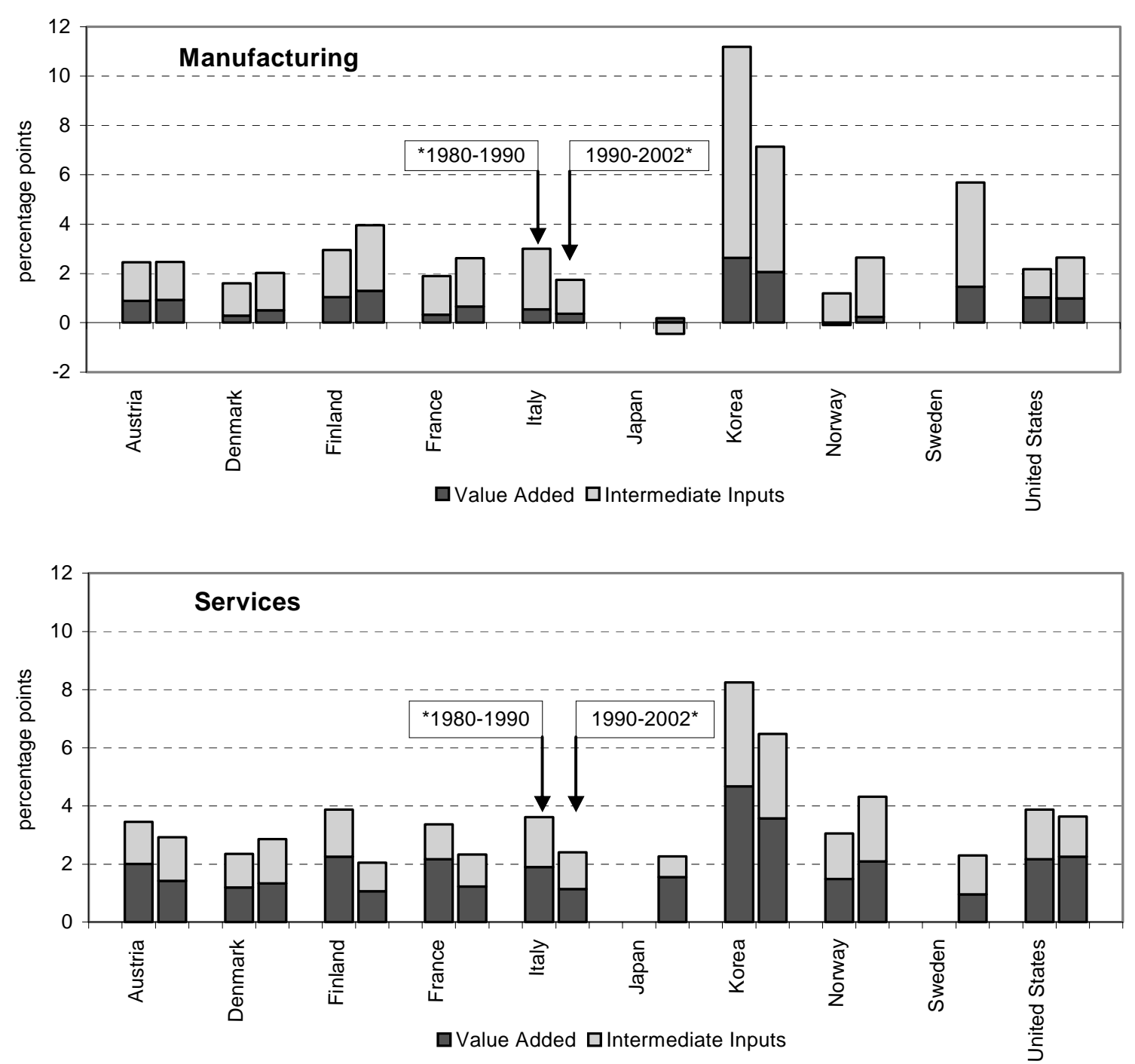

Note. The services sector covers ISIC classes 50-99. *: or nearest years available. Source: OECD STAN Database.

The services sector relies to a much lower degree than the manufacturing sector on intermediate inputs. For the countries for which data were available, intermediate inputs contributed to between one-third and one-half of the growth in gross output for the period 1990 to 2001. A relatively strong contribution of intermediate inputs to services output growth can be observed in Austria, Denmark, Italy, Norway and Sweden, while it was relatively small for the United States. The relative contribution of intermediate inputs to output growth in services has increased since the 1980s in several countries, notably Austria, Denmark, Finland and France, while it stayed constant or decreased in Italy, Korea and the United States. Overall, this suggests that services still rely more on in-house production rather than on buying-in from external sources. More generally, the evidence suggests that if there has indeed been a growing trend towards a more fragmented production process, then this trend has thus far primarily occurred in the production of manufacturing goods and only to a lesser degree in the production of services. 


\section{Inter-sectoral interactions - evidence from input-output tables}

Previous OECD work has shown that services are increasingly involved in the production of intermediate inputs (Wölfl, 2003, 2005). This is notably the case for business-related services, such as financial intermediation, transport and storage and post and telecommunications services, and to a smaller degree also for wholesale and retail trade. On average across countries, about $45 \%$ of gross output produced by these services industries is used as intermediate input by other industries. More than half of all transport and communications services, for instance, are used as intermediate inputs (Wölfl, 2003).

Figure 2 points to the increasing importance of services activities for manufacturing and the economy as a whole. It measures the extent to which services are "embodied" in manufacturing processes, i.e. the extent to which services contribute inputs to manufacturing production at any stage of the production process (see also Box 1). Take the example of a car. The car producer might subcontract specific services such as logistics to a specialised services producer. At the same time, the car is made up of many inputs that are produced in other manufacturing industries, such as wheels that are produced in the rubber products industry. However, the producer of wheels may also have bought services from a specialist service provider. Thus, in the end, services are "embodied" in both the parts that are delivered to the car producer and in the car itself.

Figure 2. Services sector value added embodied in manufacturing goods Percentage of total value of manufacturing goods in final demand

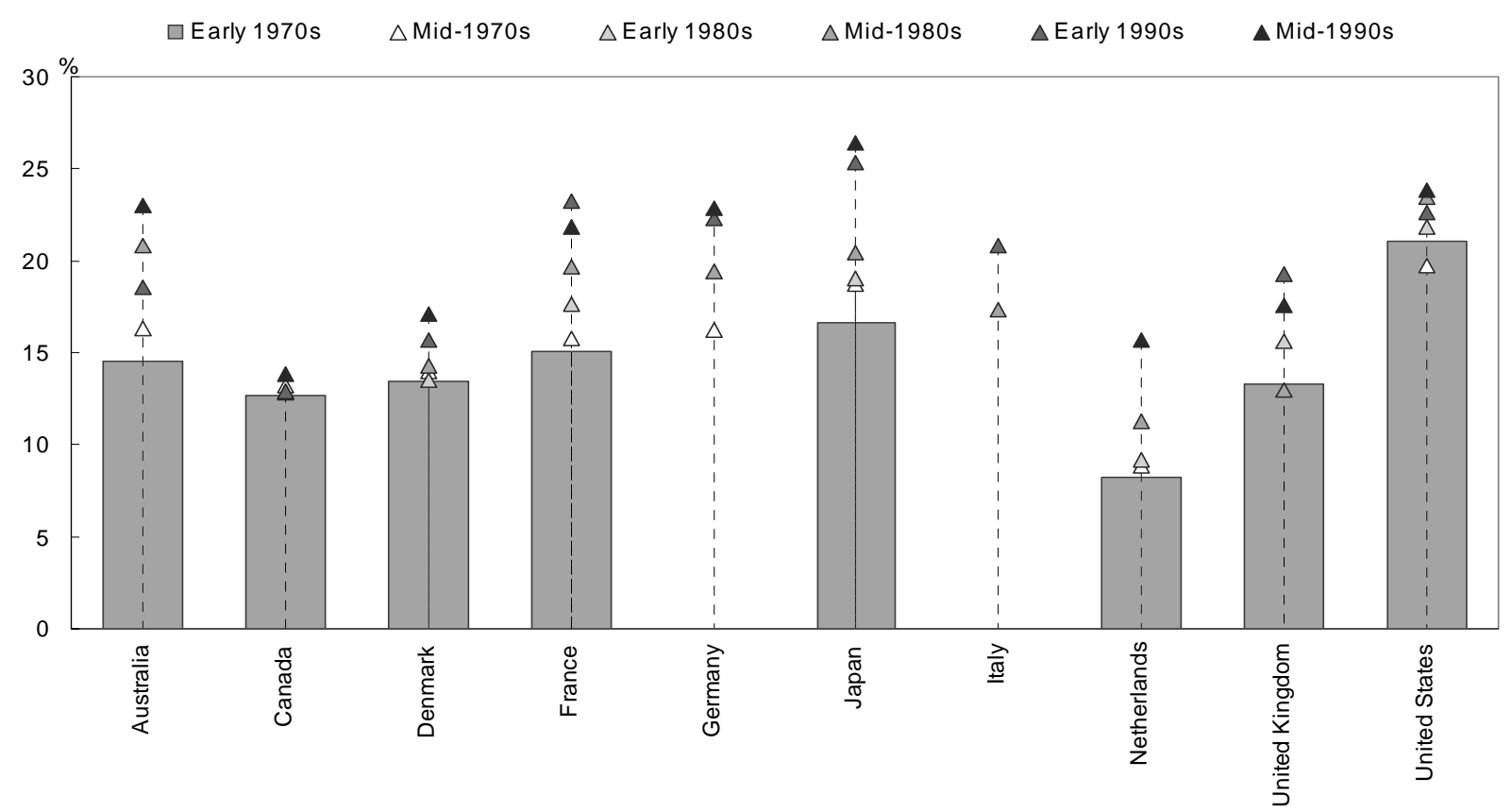

Source: OECD Input-Output tables, Science, Technology and Industry Scoreboard 2003.

In the mid-1990s, services accounted directly or indirectly for about $22 \%$ of manufacturing production. This is the average across the OECD countries for which input-output tables were available. A particularly high contribution of services can be observed for the United States, Japan, Germany and Australia. Figure 2 points to the growth in the share of services embodied in goods; the importance of services embodied in manufacturing has increased substantially since the 1970s; it doubled in certain OECD countries, notably Japan, France and Australia. 


\section{The interaction between services and manufacturing and its impact on output}

Figures 3 and 4 show how a change in final demand for services or manufacturing industries affects output in these sectors (see Box 1 for the methodology used). If total final demand for services increases by $10 \%$, and total final demand for manufacturing goods stays constant, total output will increase by about $5.5 \%$ on average across countries (Figure 3). In contrast, if total final demand for manufacturing increases by about $10 \%$, leaving the demand for services constant, total output will increase by about $3 \%$ on average (Figure 4). To a considerable degree this is due to the larger size of the service sector; any percentage point increase in output in services will raise total output more than an equivalent increase in manufacturing output. However, some of the impact of greater demand for manufacturing occurs through demand for investment goods, which is included in the capital flows of the input-output table, and ignored here.

Figure 3. Change in total output resulting from an increase in the demand for services, $1997^{1}$

Percentage increase in total output of selected industries if total final demand for services increases by $10 \%$

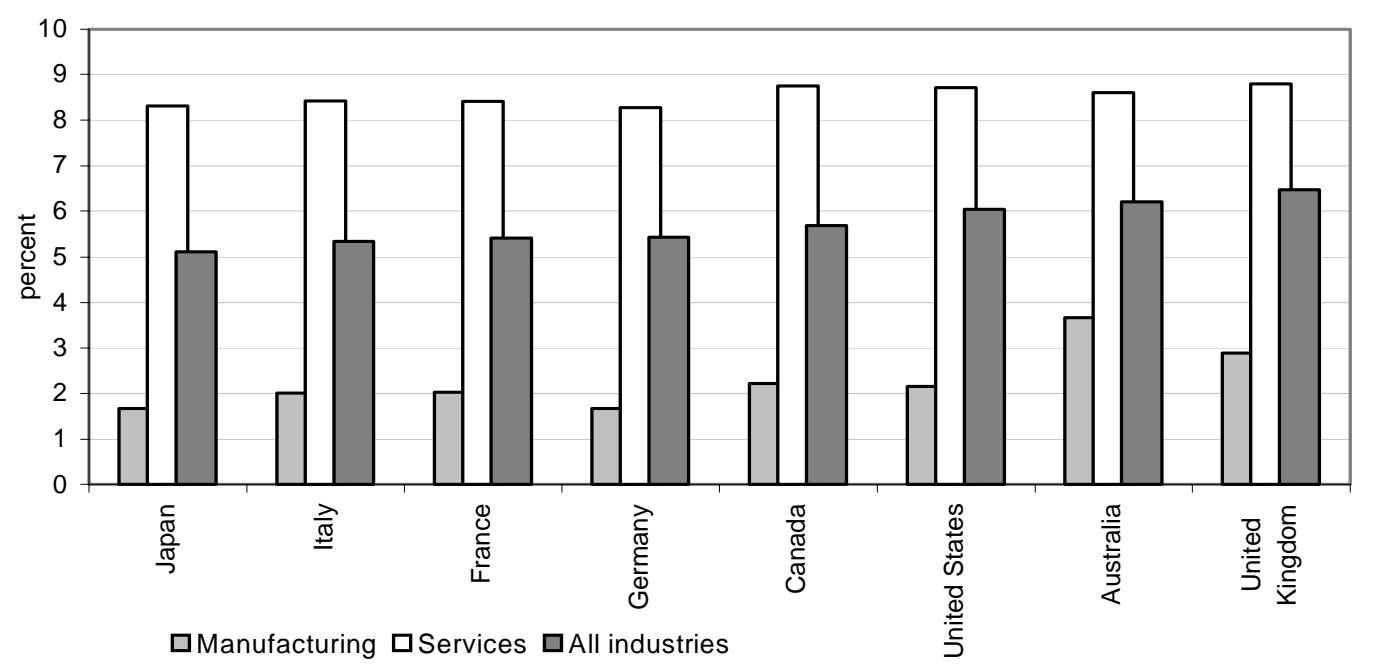

1. Italy: 1992, Australia, Germany, France, and the United Kingdom: 1995.

Source: OECD Input-Output tables.

Figure 4. Change in total output resulting from an increase in the demand for manufacturing, $1997^{1}$

Percentage increase in total output of selected industries if total final demand for manufacturing increases by $10 \%$

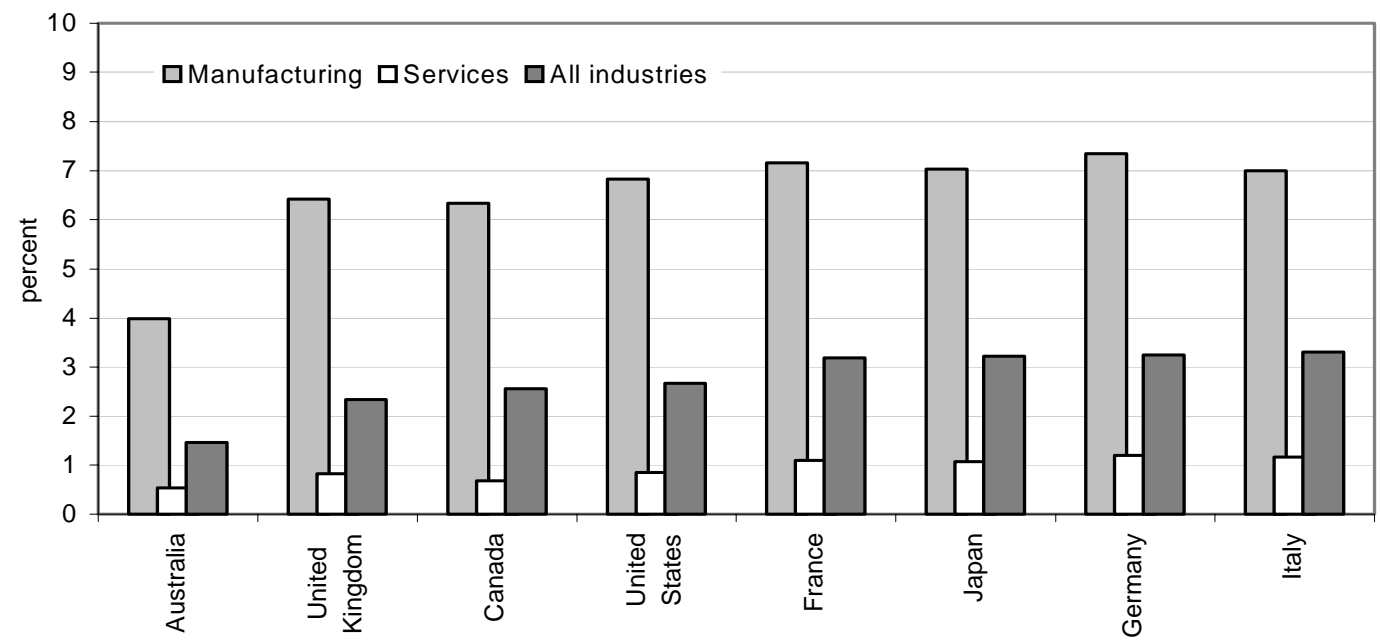

1. Italy: 1992, Australia, Germany, France, and the United Kingdom: 1995.

Source: OECD Input-Output tables 2003. 


\section{Box 1. Analysing the indirect role of services using input-output tables}

The basic relationship between gross output, intermediate demand and final demand can be written as in equations (1) and (2): Let $d_{i}$ be final demand for goods or services of industry $i, y_{j}$ gross output of industry $j$, and $a_{i j}$ be the technical coefficient, i.e. the share of inputs from industry $i$ in total production of the input using industry $j$. Then the final demand for goods or services of industry i can be written as total production of this industry minus the parts of its production that are used by other industries j. $d_{i}=y_{i}-\sum_{j=1}^{n} a_{i j} \cdot y_{j}$, where $a_{i j}=\frac{y_{i j}}{y_{j}}$

Equation (1) derives from a system of equations for each of the $n$ industries in the economy. Let $Y$ reflect the vector of industry gross output, $D$ the vector of final demand, and $A$ the matrix of technical coefficients. Then the basic relation between output and final demand can be written as:

$$
D=(I-A) \cdot Y \text {, or alternatively: } Y=(I-A)^{-1} \cdot D
$$

In this equation, $(I-A)^{-1}$ is known as the Inverse Leontief Matrix of the input-output-coefficients that describes how many units of one good or service have to be produced at any stage of the value added chain in order to produce one unit of the final demand for goods or services.

\section{Change in output with an increase in final demand for selected industries}

A simulation of the role of the interaction between services and manufacturing for industry and aggregate output examines how the output of all industries will change if total final demand for either every service or manufacturing industry increases by $10 \%$. The vector of the change in demand $\tilde{D}$ consists thus of elements $d_{j}^{1}$ of original demand for all industries, $j \in n_{j}$, for which demand is assumed to stay constant, and of $\left(1.1 \cdot d_{i}^{2}\right)$ for all industries, $i \in n_{i}$ for which demand is assumed to change. Applying equation (2), derived output $\tilde{Y}$ can be written as:

$$
\tilde{Y}=(I-A)^{-1} \cdot \tilde{D}, \text { where } \tilde{D}^{\prime}=\left(1.1 \cdot d_{1}^{2}, 1.1 \cdot d_{2}^{2}, \ldots, 1.1 \cdot d_{n i}^{2}, d_{1}^{l}, d_{2}^{l}, \ldots, d_{n j}^{l}\right)
$$

\section{Direct and indirect use of employment by industry}

The interaction between industries can also be analysed through a computed employment flow table. It is assumed that each production unit of an industry is produced with the same, industry-specific, employment-intensity of production. If this ratio is applied to all employment flows from the respective industry, the employment flow matrix can be written as:

$$
\breve{E}=\operatorname{diag}(e) \times(I-A)^{-1} \times \operatorname{diag}(D), \text { where } e_{i}=E_{i} / Y_{i}
$$

While the input-output analysis provides an appropriate tool to analyse the interaction between industries at a given point in time, some drawbacks have to be mentioned:

a) Input-output analysis does not allow an analysis of inter-temporal effects, such as substitution effects or changes in the resource allocation between industries as a response to a change in demand or output over time.

b) Input-output analysis is primarily an accounting methodology. It is thus not possible to analyse external effects, such as economies of scale or spill-overs from one industry to the other.

c) Since an input-output table with actual employment flows between industries does not exist, such a table has been computed on the basis of industry-specific employment-intensities of production. ${ }^{8}$ Applying this intensity to all employment flows from one industry, however, implicitly assumes that each intermediate unit of gross output that is used as intermediate input by other industries has the same employment intensity. It is not possible to distinguish for which type of intermediate use a specific good of a specific industry is being produced. One main drawback of this assumption is that the structural effects may not be very different from those derived from output flows.

d) The calculations in this paper are based on total-use input-output tables; any estimated increase in total output may therefore also imply to some degree an increase in imports.

The effect of a demand increase depends on the interdependencies between manufacturing and service industries. An increase in total final demand for manufacturing by $10 \%$, leaving demand for services

8. Due to differences in data coverage between the OECD STAN database and the OECD Input-Output Tables, the employment intensity of certain industries had to be approximated. This was particularly the case for some business related industries. In order to keep a low level of aggregation, the employment intensities of these industries were assumed to be equal to the employment intensity of production of the broader industry. 
unchanged, will increase total output of services by about $1 \%$ on average across countries (Figure 4). This may reflect a strong dependence of manufacturing firms on inputs from other manufacturing firms, but only a relatively small dependence on services inputs. In contrast, an increase in final demand for services by $10 \%$, leaving demand for manufacturing unchanged, will raise manufacturing output by about $2 \%$ on average across countries (Figure 3). This may reflect that services are strong users of intermediate inputs and technologies that are produced by manufacturing industries. Large effects of an increase in total final demand for services on output of manufacturing industries can be observed, in particular, for medical and precision instruments manufacturing as well as, for several countries, for office and accounting machinery manufacturing. ${ }^{9}$

Figure 5. Change in output resulting from increased demand - estimates for Japan, 1997

Change in output of selected industries resulting from a $10 \%$ increase in total final demand for wholesale and retail trade, health and social work, and motor vehicles manufacturing

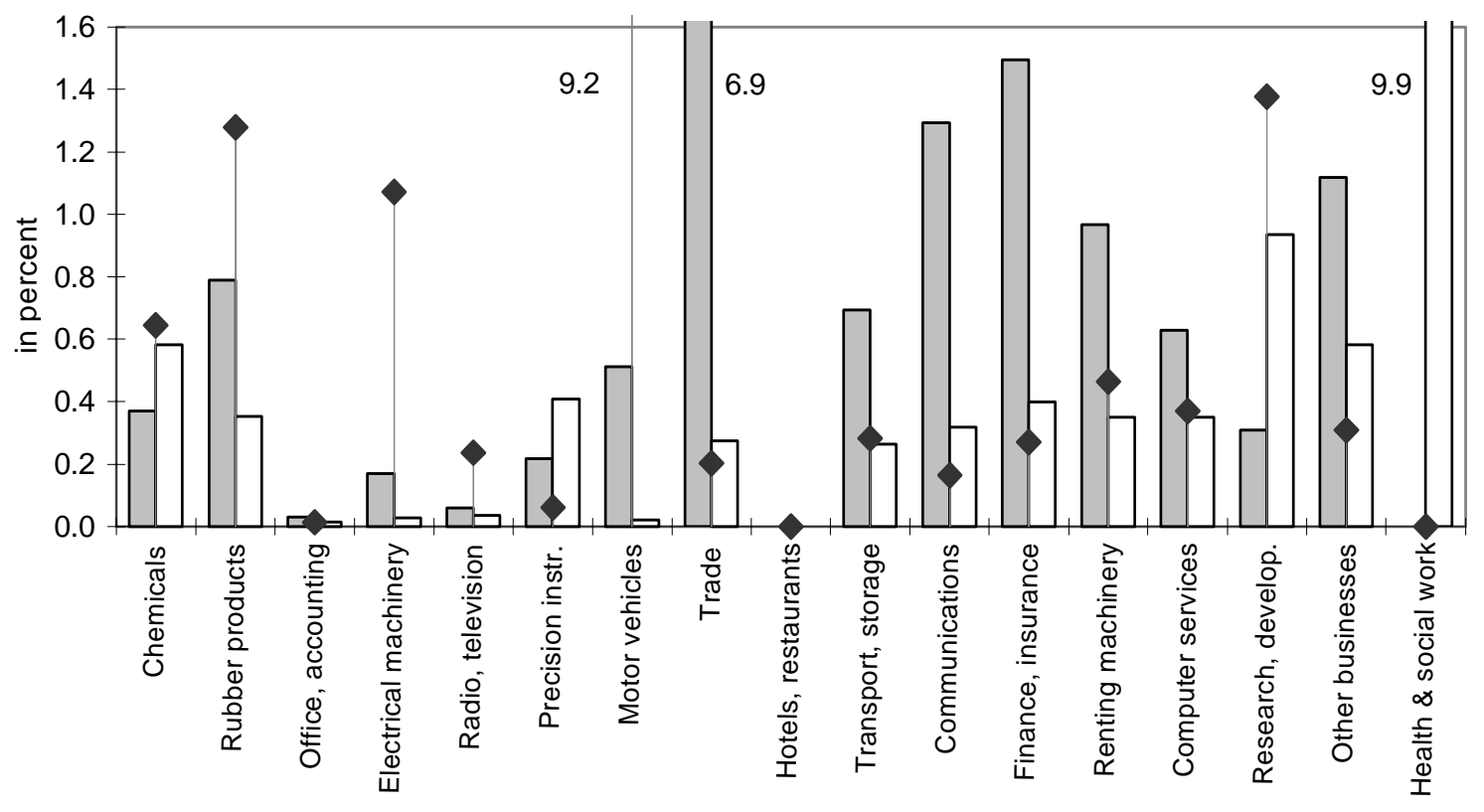

$\square$ Wholesale \& retail trade $\square$ Health \& social work $\diamond$ Motor vehicles $\mathrm{mfg}$.

Example: If total final demand for motor vehicles manufacturing increased by $10 \%$, output in R\&D services would increase by $1.4 \%$.

Source: OECD 1997 Input-Output table for Japan.

Figure 5 illustrates the interdependencies between manufacturing and service industries on the industry level, using Japan as example. It presents the effect of a $10 \%$ increase in total final demand for motor vehicle manufacturing, wholesale and retail trade and health and social work on output of selected industries. Figure 5 shows that the effect of a change in final demand for services or manufacturing industries will depend on the industry under consideration and how it is linked in the value chain to other industries. In the case of Japan, greater demand for wholesale and retail trade has considerable impacts on transport and storage, communications, finance and insurance, as well as several other business services. Moreover, an increase in total final demand for both wholesale and retail trade, as well as health and social

9. The results may also reflect problems in measuring service output. See Wölfl (2003) and Ahmad, et al. (2003). Moreover, the perceived contradiction with the results from the total intermediate inputs above results mainly from conceptual differences between industry and input-output data. While industry data look only at the ultimate direct interactions, the inverse I-O coefficients underlying the results here reflect the interaction on each step of the value added chain. See also Box 1. 
work, will also increase output in several manufacturing industries, e.g. industrial chemicals, rubber products, medical and precision instruments and motor vehicles manufacturing.

Figure 5 demonstrates that services provide intermediate inputs to many industries and thus contribute indirectly to output and productivity in many parts of the economy. This may be by outsourcing specific services from manufacturing to specialised business-related service firms, such as R\&D services, or by using specific services to improve the management of manufacturing production, e.g. via just-in-time delivery or module production. An increase in total final demand for motor vehicle manufacturing, for instance, will increase output in other manufacturing industries, notably rubber products, electrical machinery manufacturing. It will, however, also increase output in services such as renting of machinery and equipment and computer-related services. A particularly strong effect is apparent for the output of research and development services: an increase in total final demand for motor vehicles manufacturing by $10 \%$ increases output of R\&D services by about $1.4 \%$.

\section{Interaction between services and manufacturing in terms of employment flows}

Tables $2 \mathrm{a}$ and $2 \mathrm{~b}$ present results on the interaction between industries by examining employment flows between industries. Two questions are addressed: first, how do manufacturing and services industries differ in the amount of employment that is used for their own production as opposed to employment that is indirectly embodied in intermediate goods for other industries? For instance, if services employment is primarily geared towards producing final demand in other industries this may possibly indicate outsourcing of services functions to specialised services industries.

Second, in which sector is the employment that is necessary to meet direct or indirect final demand for manufacturing or services located, and are there differences in the employment structure of the services sector as compared to the manufacturing sector? For instance, is final demand for services mainly met by employment in the services sector itself or is it to a large degree met through employment of other industries, notably manufacturing, that are embodied in the intermediate inputs of the services sector?

Table $2 \mathrm{a}$ and $\mathrm{b}$ present a derived employment flow table for France as an illustration of these questions (see also Arnoldus, 2003). The table shows the employment flows between the manufacturing sector, the services sector and other industries. It distinguishes two types of employment flows, an indirect and a direct flow. The direct flow indicates how much of the employment of a sector is directly used for final demand in the same sector. The indirect flow indicates how much of the employment of a sector is used by the same or by another sector throughout the value added chain. It thus represents the employment flow of the sector that is embodied in intermediate inputs needed for the production of goods and services in the same or in another sector.

Reading the table horizontally shows the use of employment in one sector for the production of final demand production in the same or other sectors. In 1997, about 4213000 persons in France were employed in the manufacturing sector; representing about 18\% of total employment in France. 1716000 , i.e. $40 \%$ of total manufacturing employment, produced directly for final demand of the manufacturing sector, while 2496000 , i.e. about 59\%, produced goods that were used as intermediate inputs for final demand production of the manufacturing sector itself or of other sectors. Of these 2496000 persons employed in manufacturing, 1263000 produced goods that were used by other manufacturing industries, 858000 produced goods that were used as intermediate inputs in the production of final demand for services, and 375000 produced goods that were used as intermediate inputs in the production of final demand for other industries, such as agriculture and utilities. 
Table 2a. Derived employment flow table for France, 1997

Reading the table horizontally, in '000 persons and \%

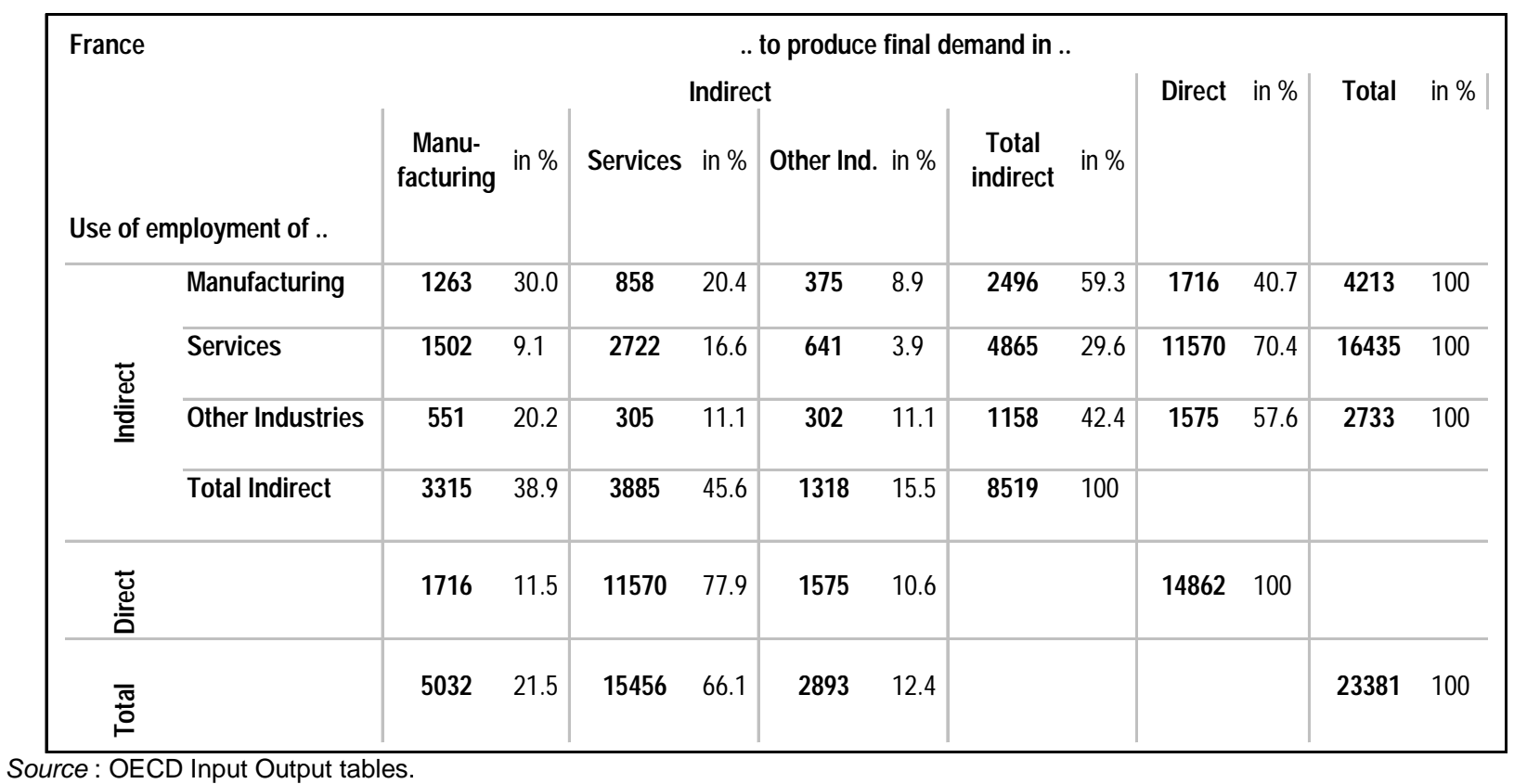

Reading the table vertically shows in which sector the employment is located that is necessary to produce final demand for a specific sector. The first column, for instance, shows the composition of employment that is used to produce final demand for manufacturing industries. Of the total 5032000 persons employed in France that were necessary to produce final demand for the manufacturing sector, 1716000 , i.e. around $34.1 \%$, were employed in the manufacturing sector and were producing directly for final demand of this sector. Another 1263000 persons, i.e. around 25.1\% of total employment necessary to produce final demand for manufacturing, were also employed in the manufacturing sector itself, and contributed indirectly to final demand production by producing intermediate inputs that were used by other manufacturing industries. The remaining $40.7 \%$ of employment necessary to produce final demand for manufacturing are employed in the services sector (1 502000 workers) or in other industries (551000 persons) and produced goods that were used by manufacturing industries as intermediate inputs. 
Table 2b. Derived employment flow table for France, 1997

Reading the table vertically, In '000 persons and \%

\begin{tabular}{|c|c|c|c|c|c|c|c|}
\hline \multirow{3}{*}{\multicolumn{2}{|c|}{$\begin{array}{l}\text { France } \\
\text { Use of employment of .. }\end{array}$}} & \multicolumn{6}{|c|}{.. to produce final demand in .. } \\
\hline & & \multirow[b]{2}{*}{$\begin{array}{l}\text { Manu- } \\
\text { facturing }\end{array}$} & \multicolumn{2}{|c|}{ Indirect } & \multirow[b]{2}{*}{$\begin{array}{l}\text { Total } \\
\text { indirect }\end{array}$} & \multirow[t]{2}{*}{ Direct } & \multirow{2}{*}{ Total } \\
\hline & & & Services & Other Ind & & & \\
\hline \multirow{4}{*}{$\begin{array}{l}\overline{\underline{8}} \\
\underline{\underline{\underline{2}}}\end{array}$} & $\begin{array}{l}\text { Manufacturing } \\
\text { in } \%\end{array}$ & $25.1^{1263}$ & 858 & $13.0 \quad 375$ & $29.3^{2496}$ & $11.5^{1716}$ & $18.0^{\mathbf{4 2 1 3}}$ \\
\hline & $\begin{array}{l}\text { Services } \\
\text { in } \%\end{array}$ & $29.8{ }^{1502}$ & $17.6{ }^{2722}$ & $22.2 \quad 641$ & $57.1^{4865}$ & $77.9^{11570}$ & $70.3^{16435}$ \\
\hline & $\begin{array}{l}\text { Other Industries } \\
\text { in } \%\end{array}$ & $10.9 \begin{array}{ll}551 \\
\end{array}$ & 305 & $10.4 \quad 302$ & $13.6^{1158}$ & $10.6^{1575}$ & $11.7^{\mathbf{2 7 3 3}}$ \\
\hline & $\begin{array}{l}\text { Total Indirect } \\
\text { in } \%\end{array}$ & $65.9^{3315}$ & $25.1{ }^{3885}$ & $45.6^{1318}$ & $100.0^{8519}$ & & \\
\hline 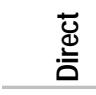 & in $\%$ & $34.1^{1716}$ & $74.9^{11570}$ & $54.4^{1575}$ & & $\begin{array}{c}14862 \\
100.0\end{array}$ & \\
\hline कृष्ठ & in $\%$ & $100 \begin{array}{ll}5032 \\
\end{array}$ & $100^{15456}$ & $100 \quad 2893$ & & & $100^{23381}$ \\
\hline
\end{tabular}

Source : OECD Input Output tables.

In general, the employment flow tables for France illustrate two main results, which are similar for most countries for which input-output tables are available (Annex 1). First, services contribute to production of the total economy through their contribution to total output and final demand as well as to total employment. About $70 \%$ of total employment consists of workers that are employed in the services sector (Table $2 \mathrm{~b}$, last column) and about $66 \%$ of total employment is required to produce final demand for services (Table 2a, bottom row). In contrast, $18 \%$ of total employment is employed in the manufacturing sector (and $22 \%$ of total employment is used to produce final demand for manufacturing).

Second, services are less integrated in intermediate input flows between industries than the manufacturing sector; they are more independent. About $75 \%$ of the total number of workers that is necessary to produce final demand for the services sector are employed in the services sector and are directly contributing to services production. Another $18 \%$ are services workers that are indirectly contributing to production, by producing for other firms in the services sector (Table $2 \mathrm{~b}$, second column, bottom row). In contrast, manufacturing industries depend much more strongly on labour input that is employed in industries other than the manufacturing sector. About $34 \%$ of the total amount of labour that is necessary to produce final demand for the manufacturing sector are manufacturing workers that are directly contributing to manufacturing production; another $25 \%$ of manufacturing workers are contributing indirectly by producing for other firms in the manufacturing sector (Table $2 \mathrm{~b}$, second column, bottom row). Moreover, while services contribute as intermediate input providers to the performance of other industries, notably manufacturing, their role is weaker than the role of manufacturing in providing intermediate inputs to other industries. About $13 \%$ of total services employment contributes indirectly to production of non-services industries, while more than $29 \%$ of manufacturing workers contribute indirectly to production of non-manufacturing output.

\section{The occupational composition}

At first sight, the previous results seem to contradict the growth of services as a provider of intermediate inputs. Two factors may, however, explain this counterintuitive result. The first factor relates 
to data availability. The most recent Input-Output tables available in the OECD database date from 1997; in the case of Italy, the latest available Input-Output table is from 1992. Although outsourcing has been around for some time, the recent trend in off-shoring of services activities to domestic or foreign specialised services providers is, however, a phenomenon that appears to have become more pronounced in the late 1990s. It may, thus, not yet be appropriately captured in the available Input-Output tables. Second, Input-Output tables can only capture some aspects of flows of goods and services between industries. Several services jobs are, however, undertaken within the manufacturing sector. This is illustrated in Figure 6, using data on occupations to examine the intra-industry employment composition of sectors.

Figure 6. Share of employment in service-related occupations in the manufacturing sector In percent of total employment of manufacturing, 1995 and 2002

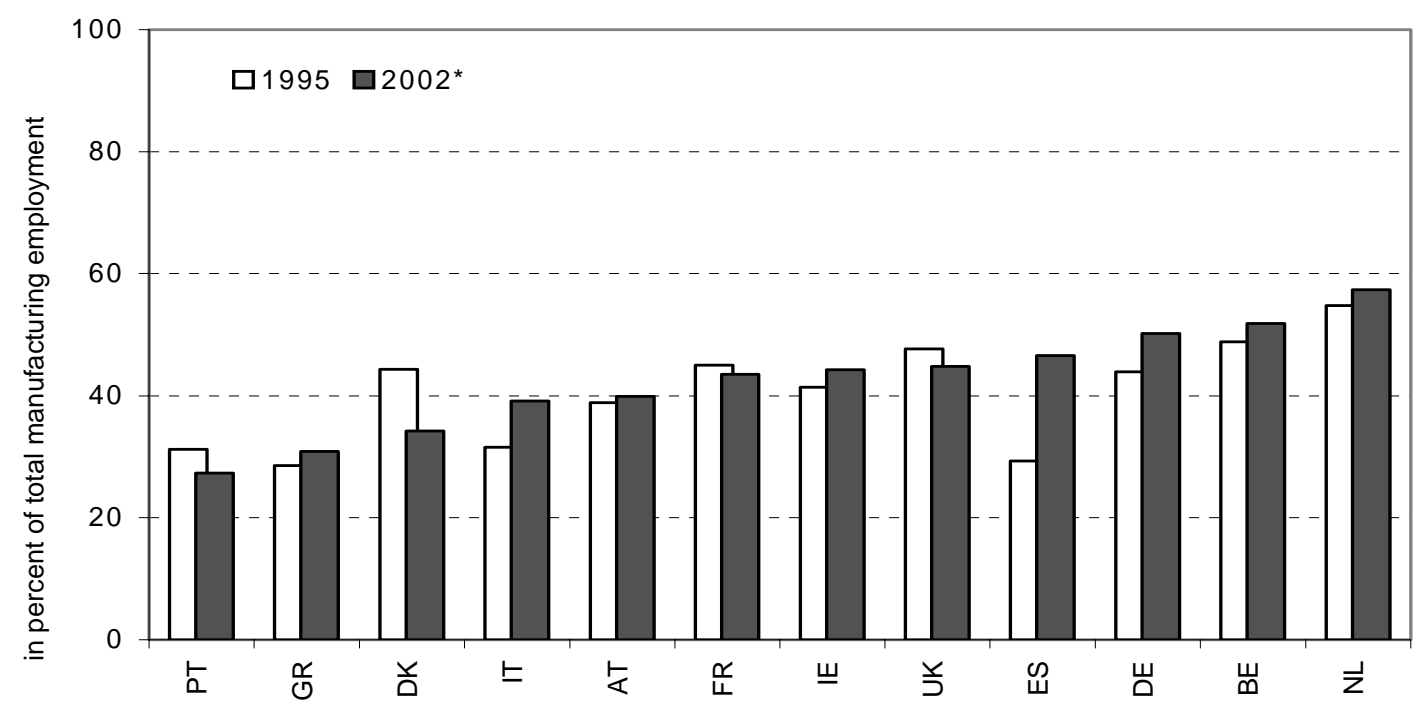

1. Services related occupations cover ISCO classes 100-500, 830, 910, 933. ${ }^{10}$ Data for Germany are from 2001. Source: EULFS, 1995, 2002.

Figure 6 shows that in 2002 on average about $40 \%$ of all persons employed in the manufacturing sector were employed in occupations that can be broadly considered as services related, e.g. management, business, finance and legal professionals. This share has declined since 1995 in the United Kingdom, Denmark and France; it has increased in the other European countries, notably Spain, Italy and Germany. ${ }^{11}$

To which extent these results reflect in- or outsourcing cannot be said unambiguously, however. In general, a trend towards outsourcing of services functions will be reflected in a declining share of services-related occupations in manufacturing firms over time. In contrast, an increase in the share of services occupations in manufacturing over time may reflect the increasing trend towards vertical integration of functions, but also towards the bundling of products and services in a package, e.g. in combining car sales with a financial package, and the changing nature of manufacturing products more generally. Table 3 provides some evidence for both trends. In most countries, the share of certain services-related occupations, notably clerical occupations, i.e. secretaries, numerical clerks, or transport

10. These occupations are: legislators, senior officials and managers, professionals and associate professionals, clerks, service workers and shop and market sales workers, as well as drivers, sales and services elementary occupations and transport workers.

11. Motohashi (2004) shows that the share of production workers in Japanese manufacturing, according to an occupation breakdown, remained relatively stable from 1994 to 2000, at about $60 \%$ of total employment. 
clerks, decreased between 1995 and 2002. It can, however, not be said a priori whether the decrease in the share of these occupations is due to outsourcing. As was suggested by Kierkegaard (2004), there are, for instance, reasons to assume that some of these jobs are no longer necessary due to the introduction of modern information and communication technologies.

In contrast to the outsourcing hypothesis, Table 3 shows an increase in certain services-related occupations within the manufacturing sector that will typically be grouped as occupations that might be threatened by outsourcing (see also OECD, 2005). This is notably the case for the group of 'other professionals' that includes occupations such as business, finance and legal professionals, trade brokers as well as administrative associate professionals. Strong increases in the share of these occupations in total manufacturing employment can in particular be observed in Denmark, Spain, Italy, the Netherlands and the United Kingdom.

Moreover, Table 3 suggest that the definition of services-related occupations is crucial for the level and the changes in the share of services-related occupations in total manufacturing employment. In Figure 6, services-related occupations are defined in a broad sense, covering occupations that are easily classified as services jobs, such as teaching and health professionals, sales workers, personal and protective services workers, but also knowledge-oriented occupations such as physical and mathematical professionals. ${ }^{12}$ Using different definitions, e.g. by excluding certain occupations from the group of services-related occupations, will alter the results depending on a country's composition of occupations. Indeed, strong increases in their shares in total manufacturing employment can be observed in physical, mathematical and engineering science professionals and associate professionals, including occupations such as physicists, chemists, computing professionals and engineers (Table 3). Due to their sciencebackground, these occupations can be classified as knowledge-related services. Whether all persons that are employed in these occupations will classify themselves as services workers is, however, questionable, and will depend on the exact job they are doing within the group of such occupations.

12. Ochel and Schreyer (1990) also use such a broad definition of services-related occupations. 


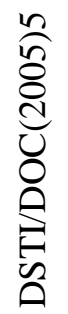

\begin{tabular}{|c|c|c|}
\hline 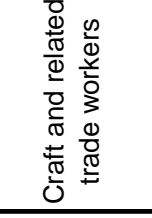 & స్ స్ & 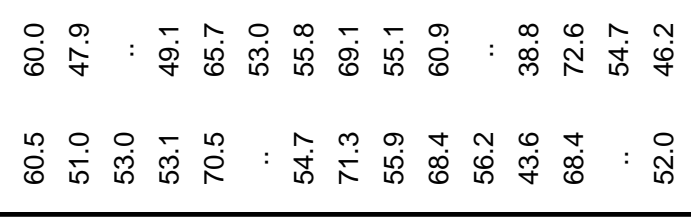 \\
\hline 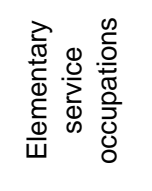 & $\begin{array}{l}\stackrel{\mathscr{\Omega}}{\circ} \\
\stackrel{\circ}{2}\end{array}$ & 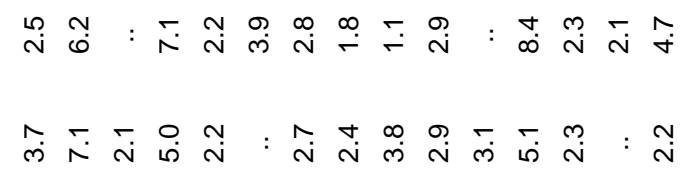 \\
\hline 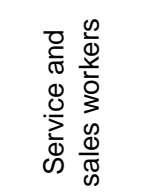 & ఫ్ & 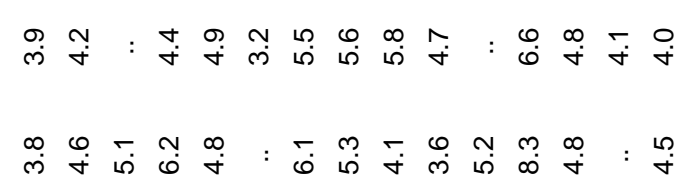 \\
\hline 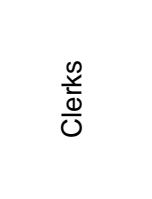 & ঐे & 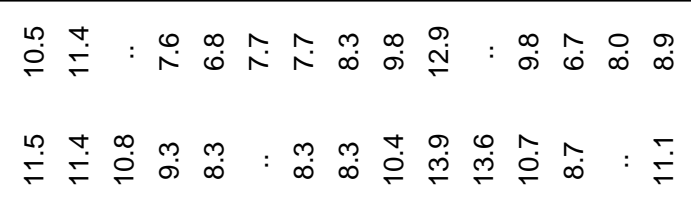 \\
\hline 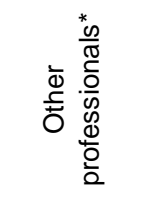 & ঐे & 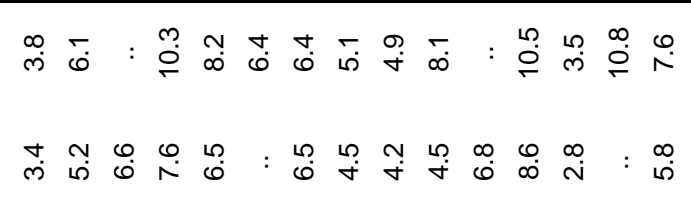 \\
\hline 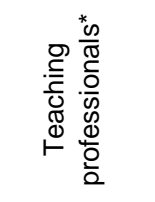 & ণิ & 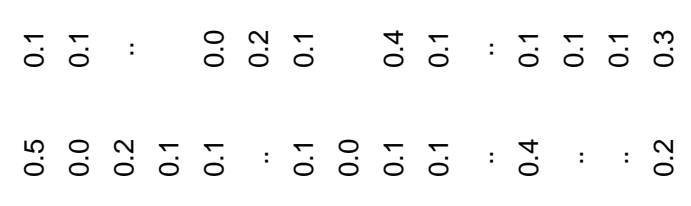 \\
\hline 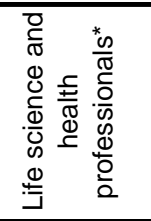 & ๙ิ๊ & 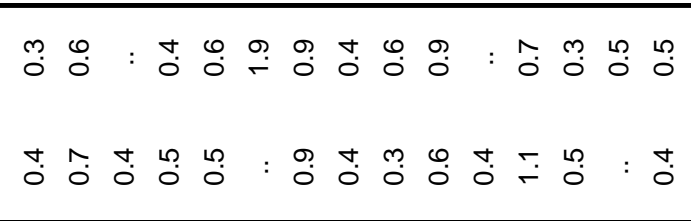 \\
\hline 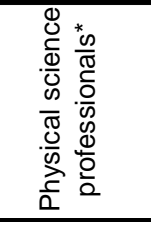 & ๙ิ & 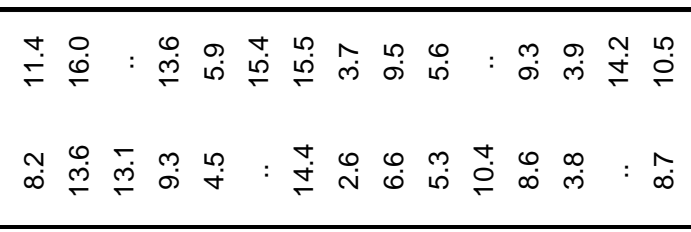 \\
\hline 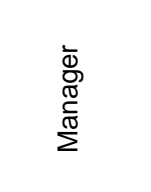 & ণิ & 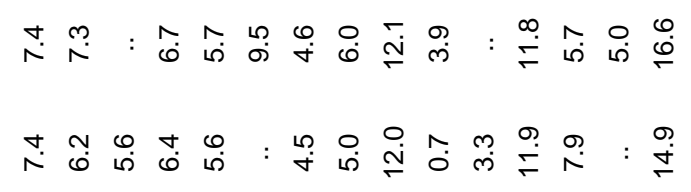 \\
\hline & & 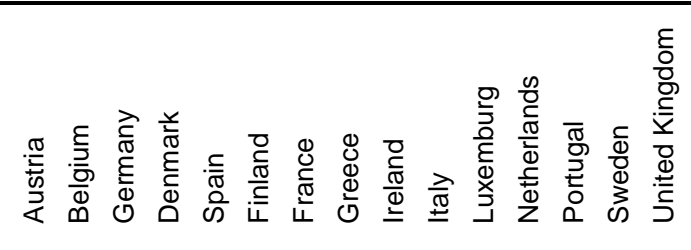 \\
\hline
\end{tabular}

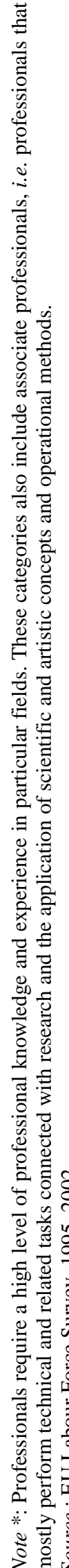




\section{Firm-level studies on the manufacturing-services interaction}

The aggregate data used above provide some helpful insights into the interaction between services and manufacturing, but are not able to address some key questions, e.g. as regards the changing sources of value in enterprises. To address such questions and move beyond anecdotal information, micro data are required. This typically implies a need for collaborative work with statistical offices, since access to such data is typically restricted as the data are collected by statistical offices under strict legal arrangements. This note provides preliminary findings from work with micro data that was carried out by five statistical offices, namely the NSOs of Canada, Denmark, Finland, New Zealand and Sweden, as well as for Japan.

Two different empirical exercises were carried out, depending on data availability in each country. The first exercise used micro data to calculate the share of turnover and total employment attributed to manufacturing sectors versus service sectors using the enterprise as the unit of observation (this is the unit of observation used to construct European Structural Business Statistics). Moreover, statistical offices were also asked to calculate these indicators by using the establishment or local activity unit as the unit of observation, which is the statistical unit used in several non-European countries. The scarce available evidence suggests that this choice of statistical unit can make an important difference in interpreting the shift from manufacturing to services sectors. For example, the economic activity of an individual enterprise might be assigned to one specific activity, even though the enterprise might cover a range of establishments engaged in various economic activities. Breaking the economy down according to the two measures might show whether there is indeed a large amount of diversification within enterprises.

The second exercise in this project used micro data to look at the composition of turnover within enterprises. It examined data on secondary products (products that are not the primary output of an establishment or enterprise) that are available from production surveys or other sources, notably focusing on the production of services products by manufacturing enterprises. Such data can show whether enterprises are indeed drawing a larger amount of their total turnover from services production.

\subsection{The structure of economies according to enterprise and establishment data}

\section{Results for Canada}

The first exercise carried out by NSOs concerned the breakdown of turnover and employment on the basis of different statistical units. In Canada, this breakdown was conducted with three different statistical units, namely for locations, establishments and enterprises (see Annex 2 for definitions). The difference between the breakdown of the economy between statistical units on locations and establishments is fairly small. However, there is a noticeable difference between the breakdown according to establishment and enterprise units, especially for the breakdown of revenues (Figure 7). This suggests a considerable degree of diversification at the enterprise level.

Figure 8 suggests that a considerable part of this difference is linked to the role of wholesale trade. Presumably, several manufacturing enterprises receive part of their revenue from wholesale services that they provide through separate wholesale establishments. The revenues from these services are allocated to manufacturing when data are collected by enterprise and to wholesale trade when the data are collected by establishment. Other substantial differences between the breakdown based on establishment and enterprise data can be observed for the mining sector and for finance and insurance services. Some of this difference may also be allocated to "Management of Companies and Enterprises", which is a separate sector in the North American Industrial Classification (NAICS) and which is a somewhat more important sector in terms of total revenues when examined with establishment data rather than with enterprise data. 
Figure 7. Breakdown of employment and revenues, Canada (in \%)

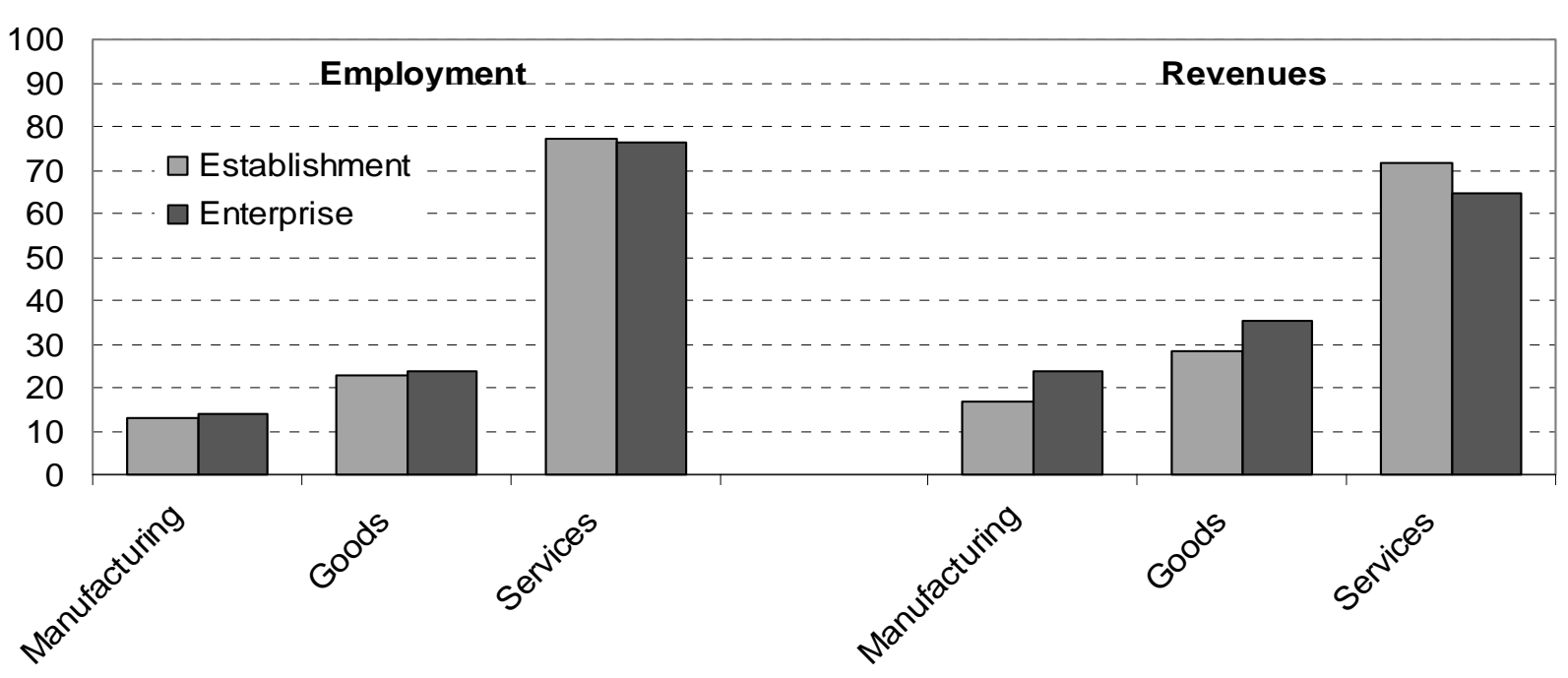

Source: Statistics Canada, see Annex 2.

Figure 8. Breakdown of revenues by sector of economic activity, based on establishment and enterprise data, Canada, in \%

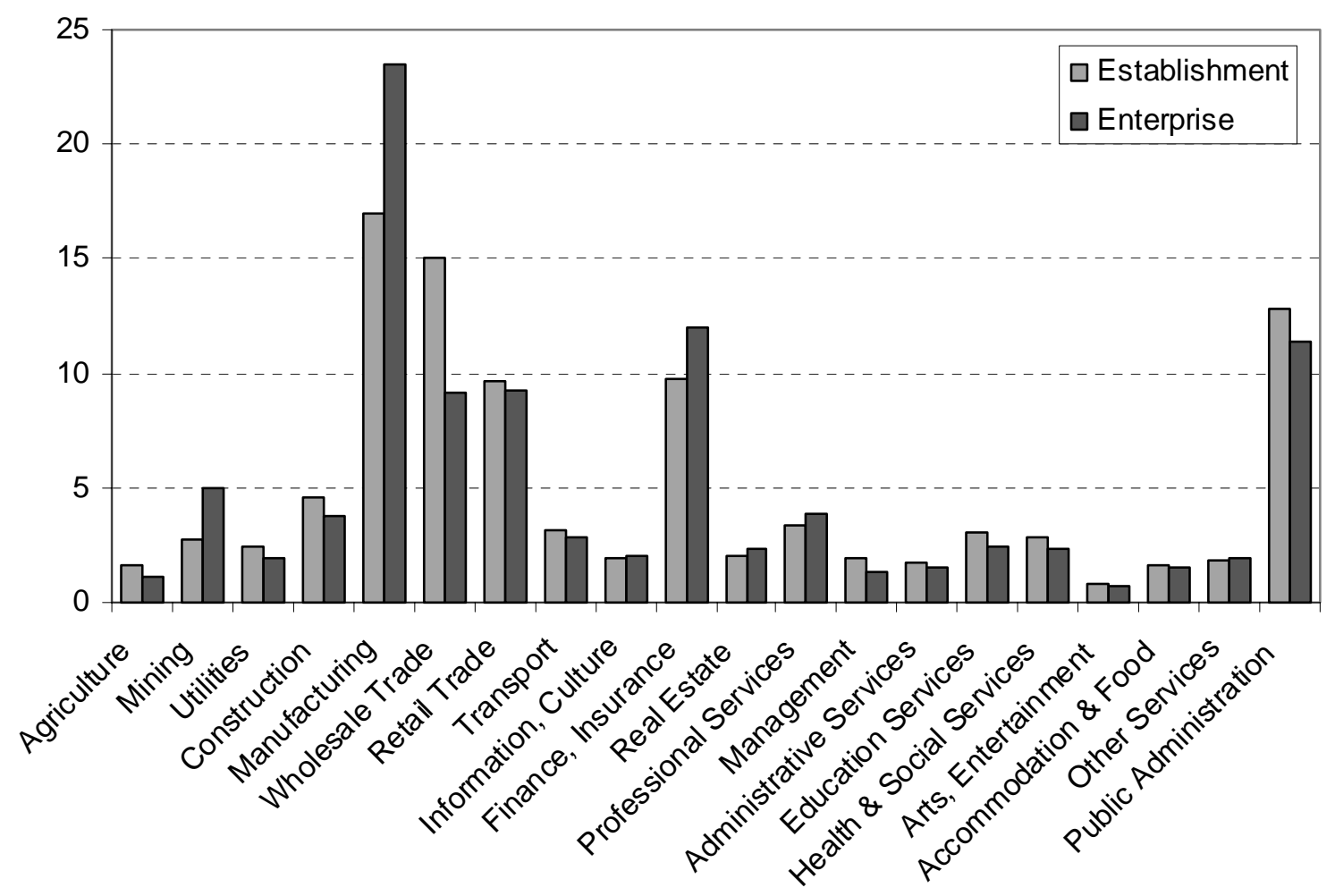

Source: Statistics Canada, see Annex 2. 


\section{DSTI/DOC(2005)5}

\section{Results for Denmark}

Data on the turnover and employment of enterprises and establishments for Denmark are available in some detail from 1999 to 2002 . These suggest that in 1999 , about $25.1 \%$ of turnover was produced in the manufacturing sector according to enterprise data, compared with $26.2 \%$ according to establishment data. In 2002, the share of manufacturing was identical in both measures, at 23.9\% (Figure 9). For services (NACE G-K), the difference between the two statistical units was also small, with about $65 \%$ of all 2002 turnover being due to services according to enterprise data, compared with $64.9 \%$ according to establishment data.

Figure 9. Breakdown of turnover and employment by economic activity, according to enterprise and establishment, Denmark, 2002, in \%

Breakdown of turnover, 2002

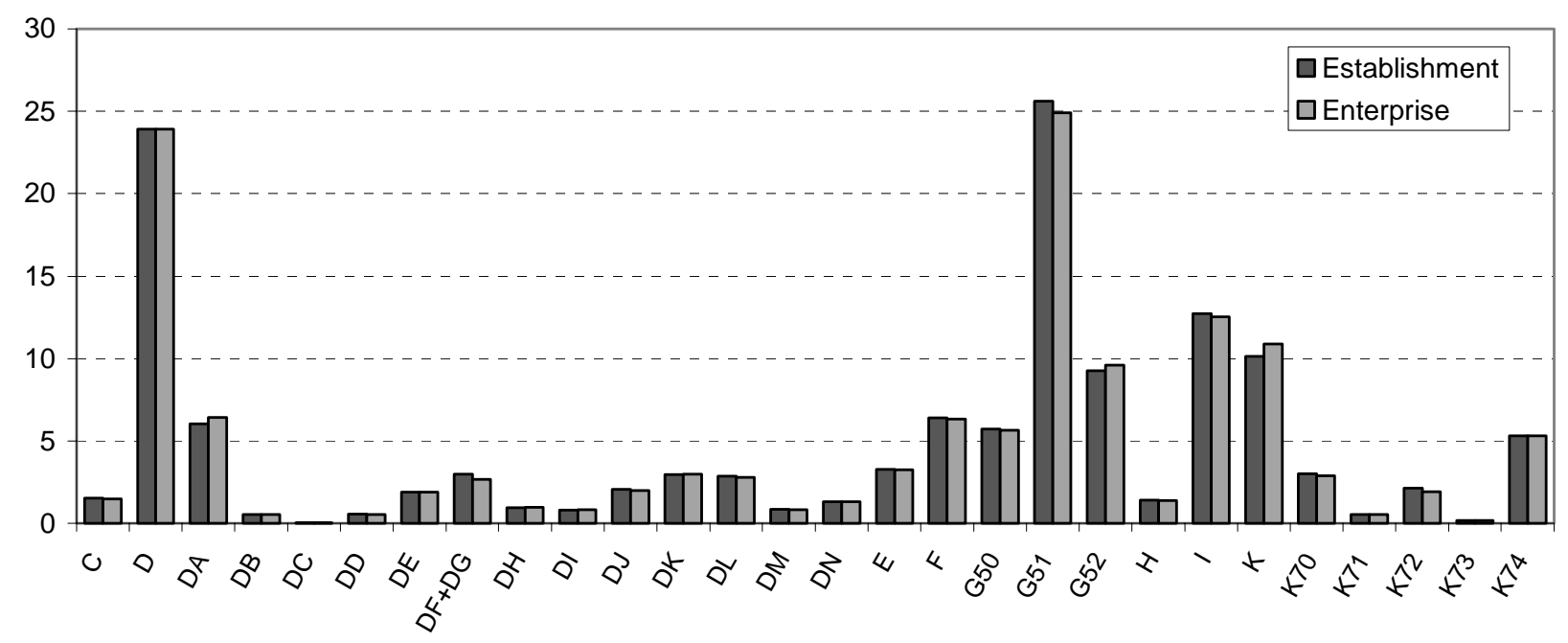

Breakdown of employment, 2002

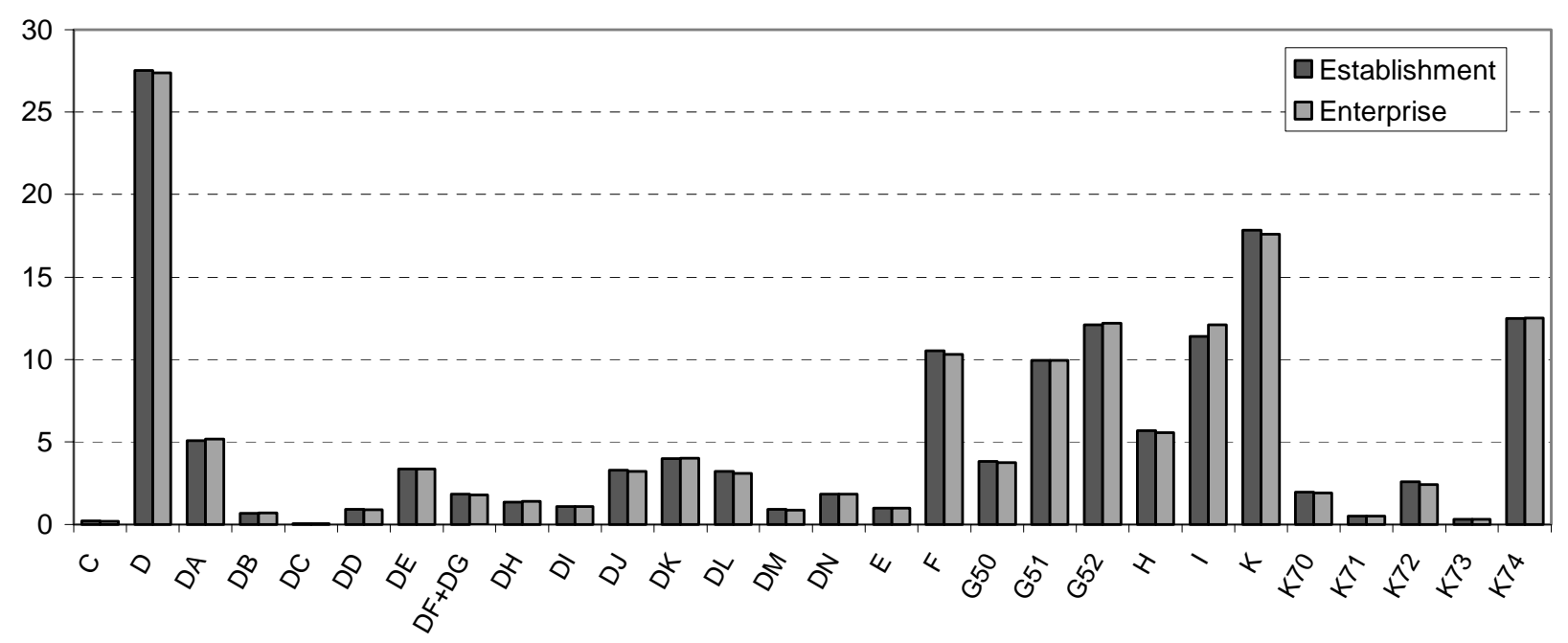

Note: The letters refer to NACE categories.

Source: Statistics Denmark. 
Data on full-time equivalent employees shows that in 1999, 36.6\% of all full-time employees were in manufacturing according to enterprise data compared with $36.8 \%$ according to establishment data. For 2002 , data for all persons employed are available for both statistical units, which show that about $27.4 \%$ of all persons employed were in manufacturing according to enterprise data, compared with about $27.5 \%$ according to establishment data. Overall, these results suggest that in the Danish case, the composition of the economy is not affected by the choice of statistical unit.

More detailed examination of the findings, with 2002 data (Figure 9), suggests that the differences are due to only a few industries, notably petroleum and chemical products (NACE DF+DG), wholesale trade (NACE G51), transport, storage and communication (NACE I) and real estate and business services (NACE K).

\section{Results for Finland}

The data for Finland enable an analysis of the breakdown of the economy according to enterprise and establishment units over the 1988-2002 period (see Annex 3). This shows that the gap between the breakdown according to the two statistical units has narrowed in Finland in recent years (Figure 10). In 1988 , about $36.4 \%$ of total revenue according to the enterprise unit was accounted for by manufacturing, against $32.6 \%$ according to the establishment unit, a sizeable gap between the two measures. In 2002, $38.8 \%$ of total revenue was due to the manufacturing sector according to enterprise data, compared with $37.3 \%$ according to establishment data. The same pattern can be observed in the data for the services sector. Similar to the experience for Canada, the difference between the two statistical units is much larger for the revenue data than for the employment data, where there is little difference between the two units, in particular for the services sector.

A more detailed look at the different industries shows that the gap between the two units has particularly declined for certain industries (Figure 11), notably for wholesale trade (NACE G51), food products (NACE DA), coke, petroleum products and nuclear fuel (NACE DF) and chemical products (NACE DG). Overall, this suggests that the difference between statistical units does not play a large role in the Finnish context and that this difference has declined over time. 
Figure 10. Breakdown of revenues and employment by main economic activity according to enterprise and establishment data, Finland, 1988-2002

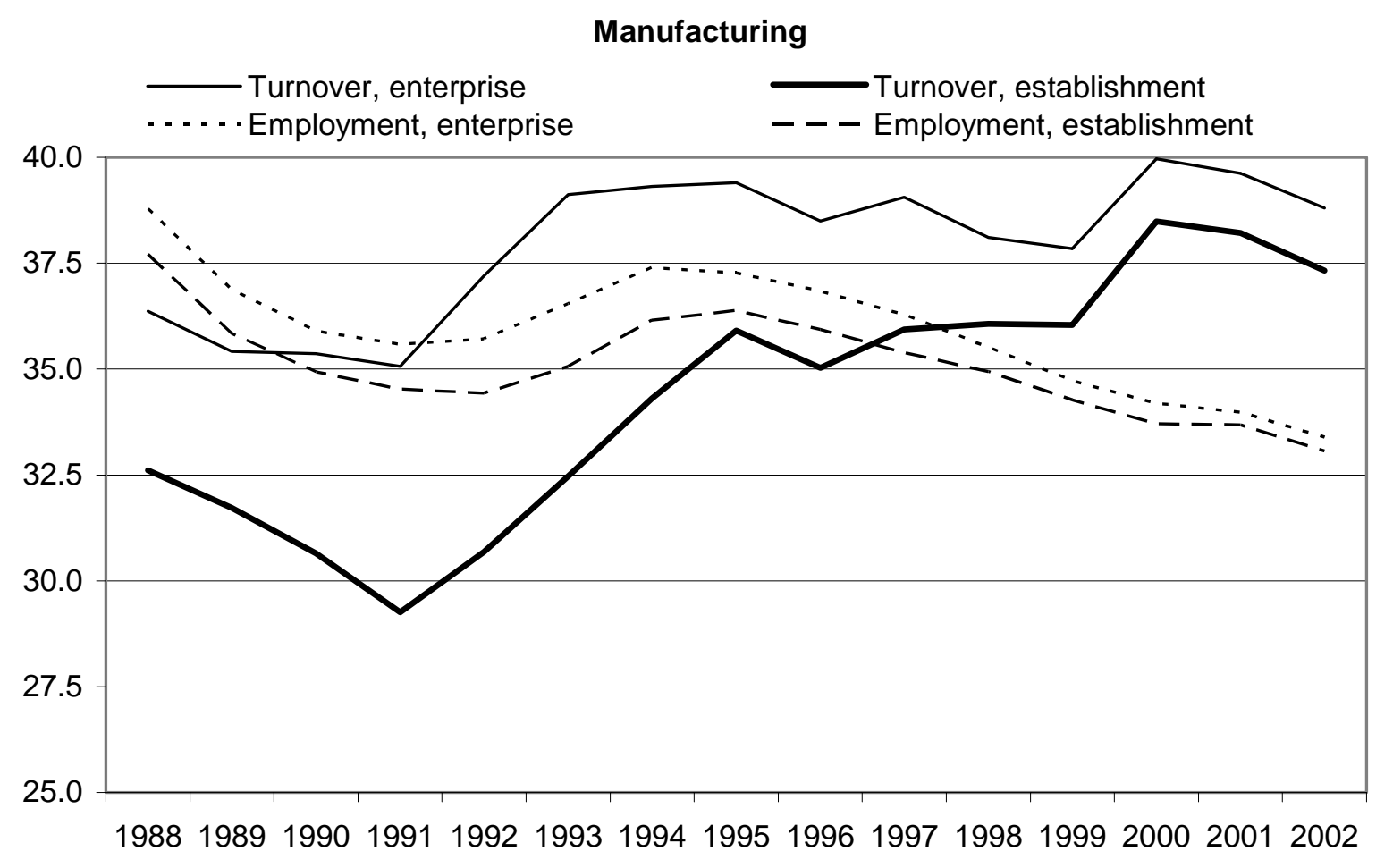

\section{Services}

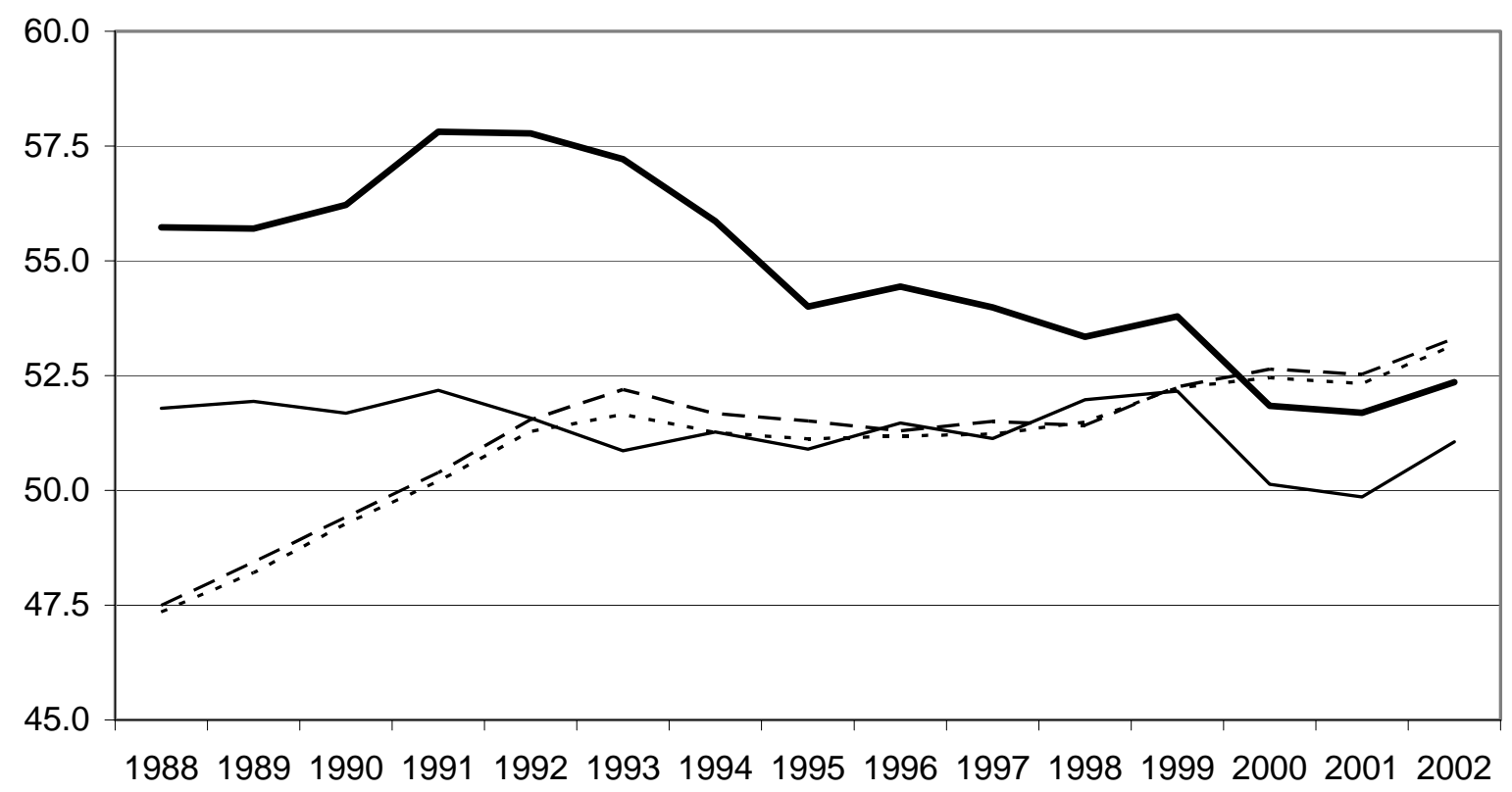

Source: Statistics Finland, see Annex 3. 
Figure 11. Breakdown of turnover by economic activity, according to enterprise and establishment, Finland, 1988 and 2002 , in $\%$

Breakdown of turnover, 1988

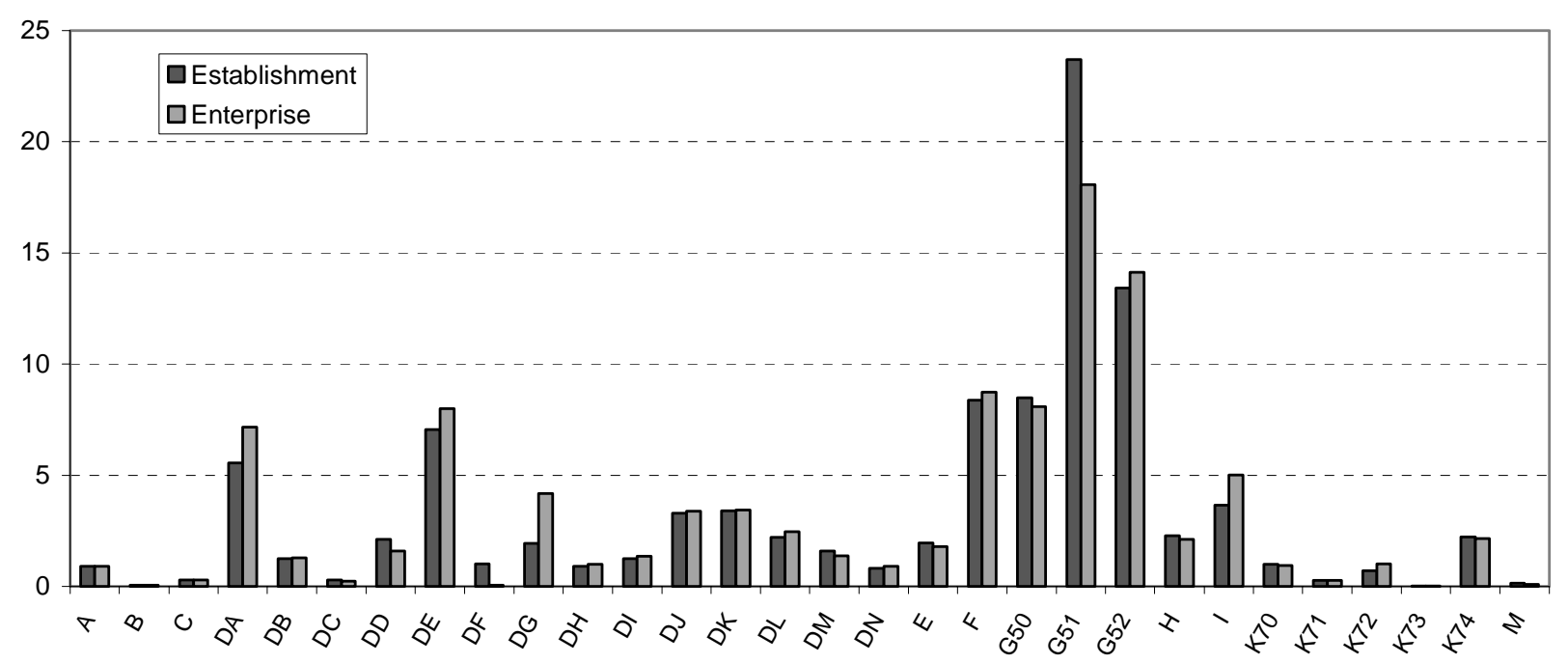

Breakdown of turnover, 2002

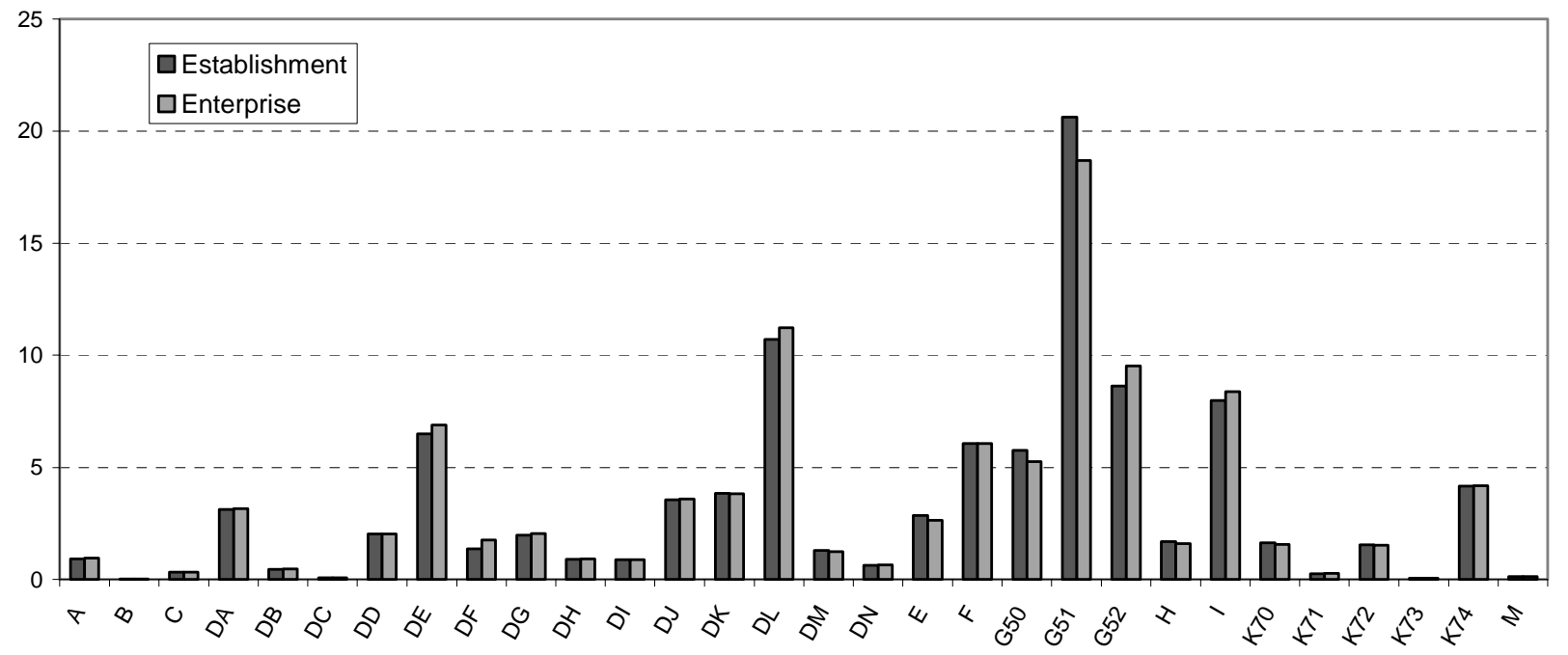

Note: The letters refer to NACE categories. G51 refers to wholesale trade.

Source: Statistics Finland, see Annex 3.

\section{Results for New Zealand}

Data for New Zealand also enable a breakdown of turnover according to two statistical units. The kind-of-activity unit is defined as a subdivision of an enterprise consisting of a set of one or more activity units for which a single set of accounting records are available. The enterprise is defined as a business or services entity operating in New Zealand. It can be a company, partnership, trust, estate, incorporated 
society, producer board, local or central government organisation, voluntary organisation or self-employed individual. Data on turnover for these two units is available from 1992 to $2003{ }^{13}$

Figure 12 shows that there is very little difference in the composition of turnover according to the two statistical units. This is confirmed by Figure 13 which shows only a small difference between the share of manufacturing in total turnover according to the two statistical units over the 1995-2003 period. This may be due to a low level of diversification of enterprises in New Zealand.

Figure 12. Breakdown of turnover by economic activity, according to enterprise and kind-of-activity unit New Zealand, 2003, in \%

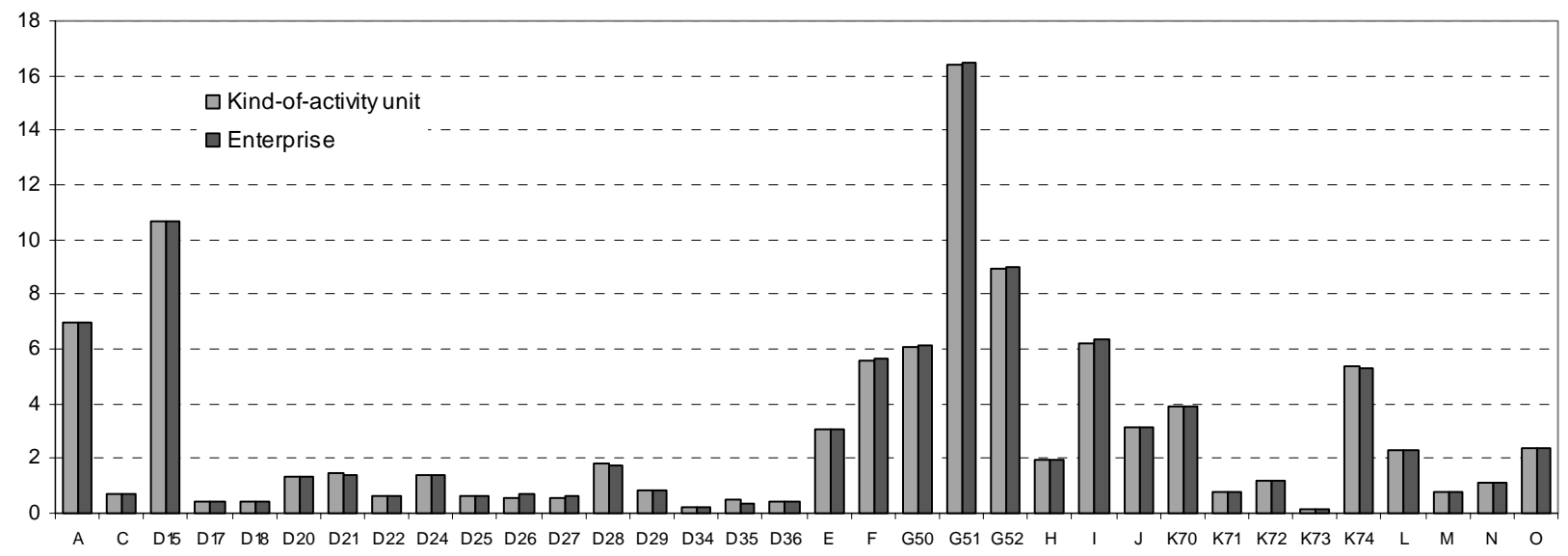

Note: The letters refer to NACE categories.

Source: Statistics New Zealand.

Figure 13. Share of manufacturing turnover in total non-agricultural turnover, by statistical unit New Zealand, 1995-2003, in \%

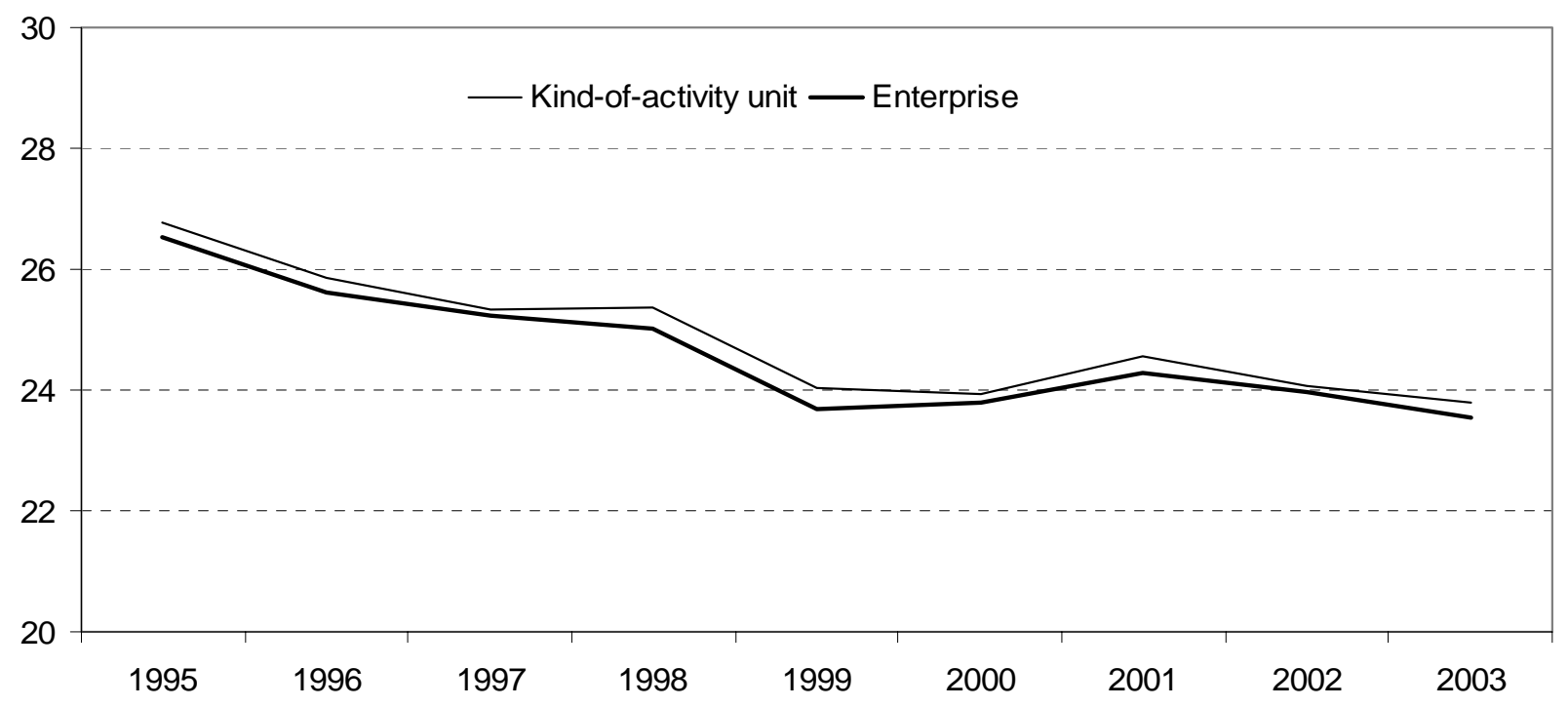

Source: Statistics New Zealand.

13. The data presented in this paper covers 1995-2003, since there were some changes in the design of New Zealand's Annual Enterprise Survey (AES) in its early years. 


\section{Results for Sweden}

Similar results can also be derived for Sweden, though for a somewhat shorter time period than for Finland (see Annex 4). The results for Sweden suggest only a small difference between the breakdown according to enterprise and establishment unit. According to enterprise data, about $30.9 \%$ of total turnover in 2002 was accounted for by the manufacturing sector, compared with about $30.3 \%$ according to data by local kind of activity unit (LKAU). For employment, the respective shares were $33.4 \%$ for the enterprise unit and 33\% for the LKAU unit. As in the case of Finland, this difference was somewhat more substantial in 1997. At that time, $32.7 \%$ of turnover according to enterprise data was due to manufacturing compared with $31.4 \%$ for the LKAU unit. For employment, the respective shares were $36.7 \%$ according to the enterprise unit and $35.2 \%$ according to the LKAU unit.

Figure 14. Breakdown of turnover by economic activity, according to enterprise and establishment, Sweden, 1997 and 2002, in \%

Breakdown of turnover, 1997

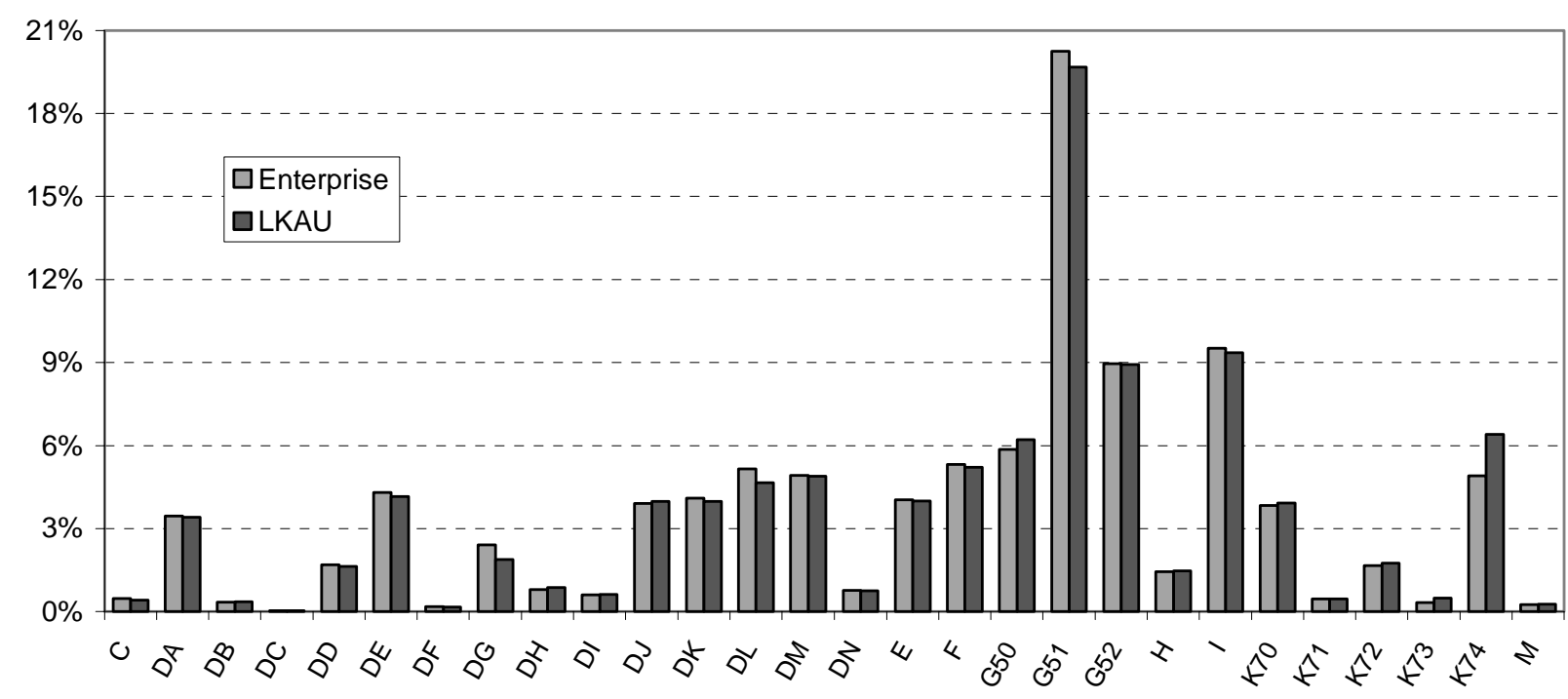

Breakdown of turnover, 2002

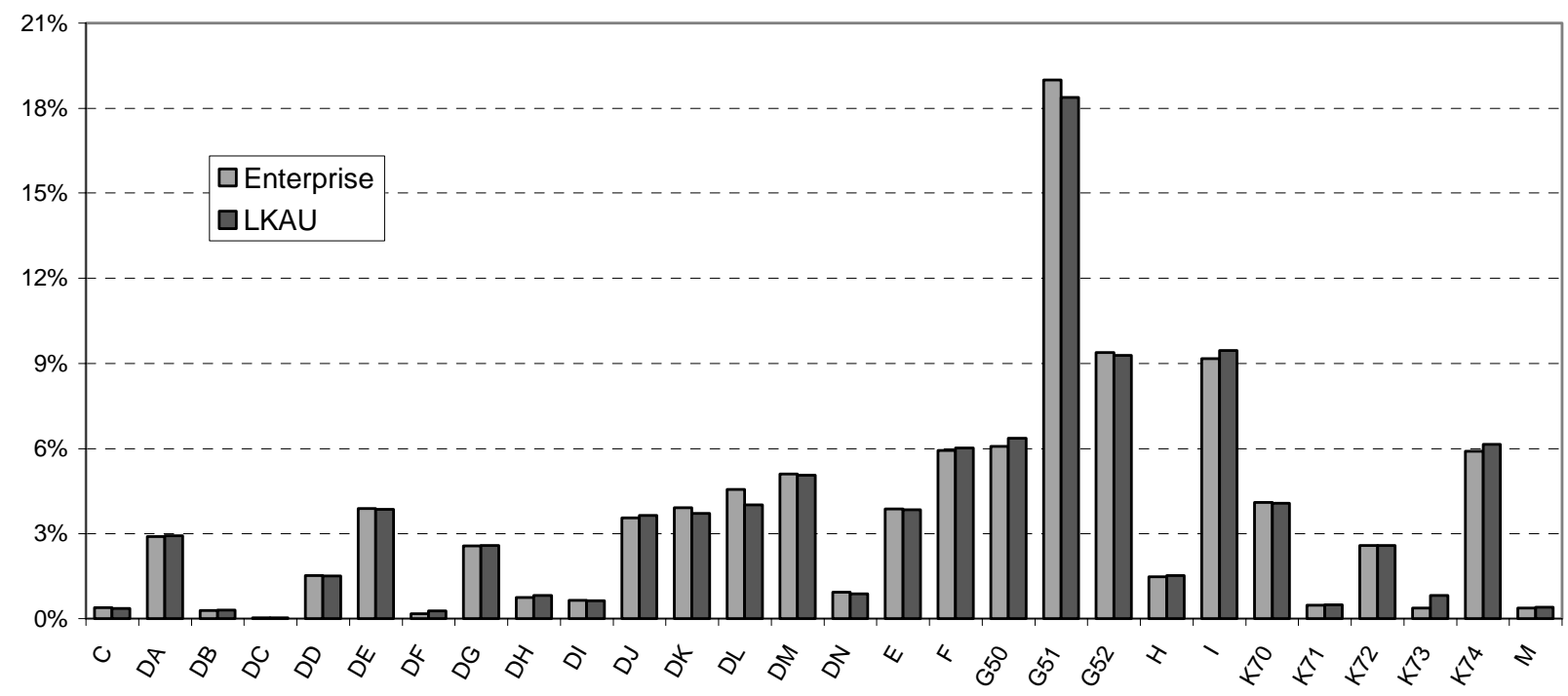

Note: The letters refer to NACE categories. G51 refers to wholesale trade. Source: Statistics Sweden, see Annex 4. 


\section{DSTI/DOC(2005)5}

A more detailed look at the Swedish data also suggests that there are only small differences for the detailed industry data (Figure 14). In 1997, the largest differences between the units as regards revenue data can be observed for other business activities (NACE K74), wholesale trade (G51), chemical products (NACE DG) and electrical and optical equipment (NACE DL). In 2002, the gap between the units for these industries had diminished considerably for chemical products and other business activities, but had increased somewhat for wholesale trade and for electrical and optical equipment. Overall, however, there is little evidence that the choice of statistical unit has a large impact on the measurement of structural differences in the Swedish economy (see also Annex 4).

\subsection{Turnover by activity and product}

\section{Results for Finland}

The second exercise of the work used product data to break down the turnover of the manufacturing sector in different products (manufacturing products, services or other sales). This breakdown was carried out by Finland, Japan, New Zealand and Sweden. For Finland, several types of secondary activity could be distinguished over the period from 1998 to 2002 (Annex 3). Figure 15 shows the breakdown of total manufacturing turnover by type of activity. It shows that turnover from services activities now accounts for over $15 \%$ of turnover in the manufacturing sector. Moreover, this share has grown considerably since 1998, when it accounted for less than $8 \%$ of total turnover in manufacturing. Turnover from other activities accounts for only a small share of turnover in the manufacturing sector.

Figure 15. Share of manufacturing turnover by activity, Finland, 1998-2002 (in \%)

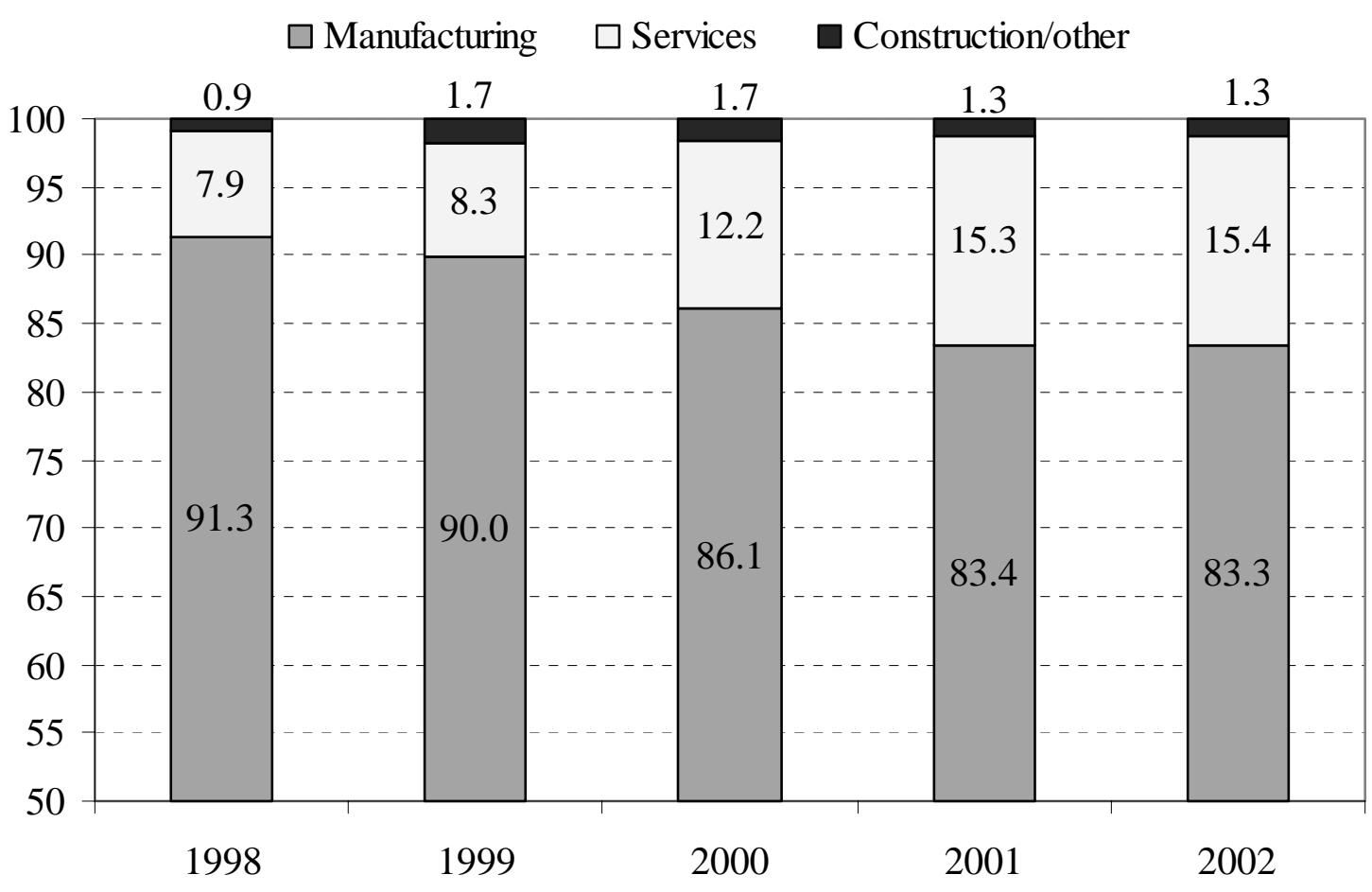

Source: Statistics Finland, see Annex 2. 
The results for turnover in the services sector are shown in Figure 16. These suggest that only a very small part of turnover in this sector consists of other activities. The share of manufacturing turnover amounted to about $0.8 \%$ of total services sector turnover for most of the period, but doubled in 2002, to $1.6 \%$. Overall, the results suggest that the manufacturing sector is increasingly engaged in services activities, whereas the services sector mainly produces services.

More detailed data suggest that not all manufacturing sub-sectors are equally geared towards services activities (Figure 17). In 2002, the industry with the largest share of turnover from services activities was electrical and optical equipment, amounting to almost $33 \%$ of total turnover. This industry accounts for the bulk of the increase in services turnover for the total manufacturing sector.

Figure 16. Share of services turnover by activity, Finland, 1998-2002 (in \%)

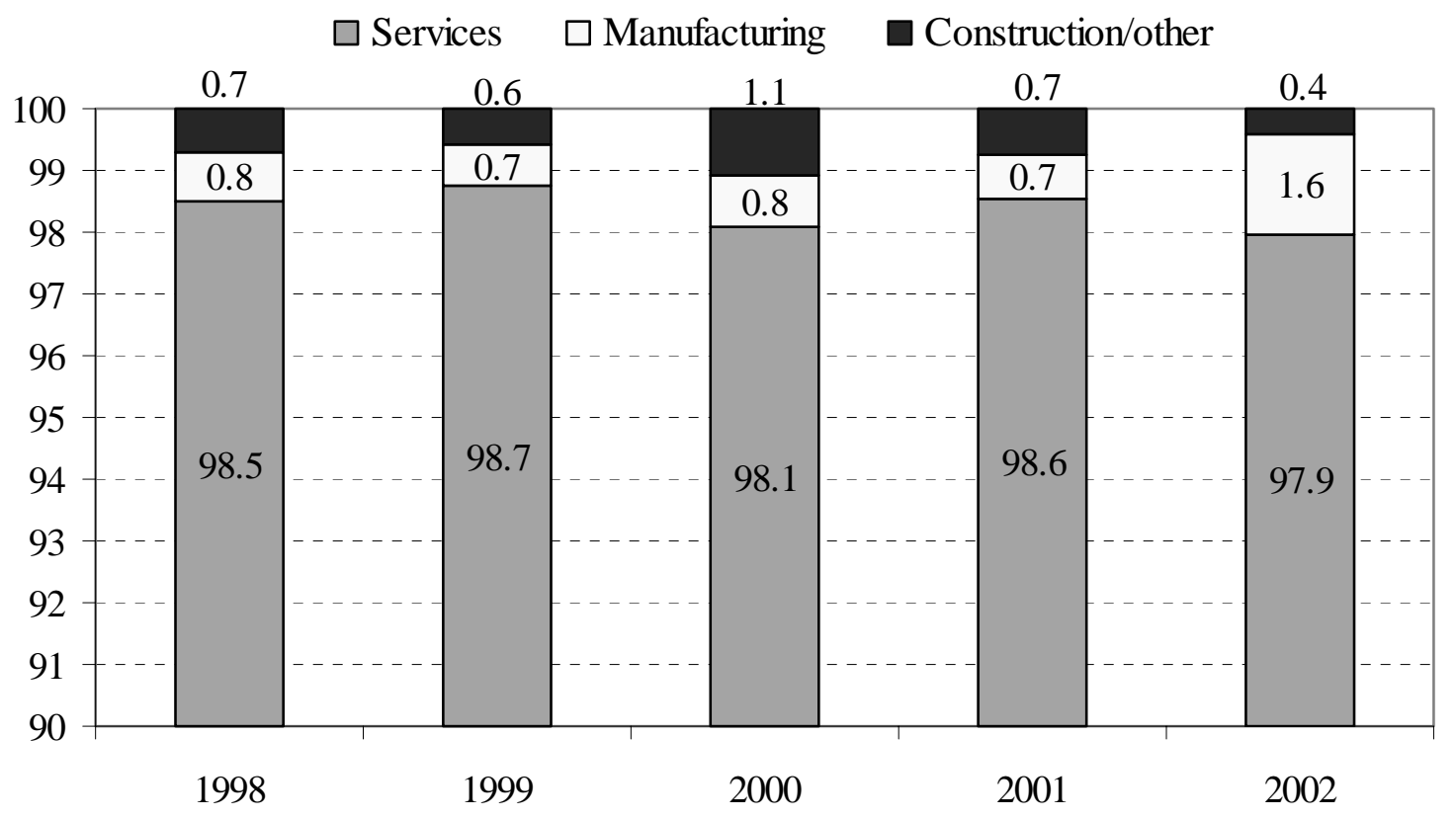

Note: Services are defined as NACE G-K, i.e. ISIC 50-74. Source: Statistics Finland, see Annex 3. 
Figure 17. Share of turnover from services activities in manufacturing industries, Finland, 1998 and 2002 (in \%)

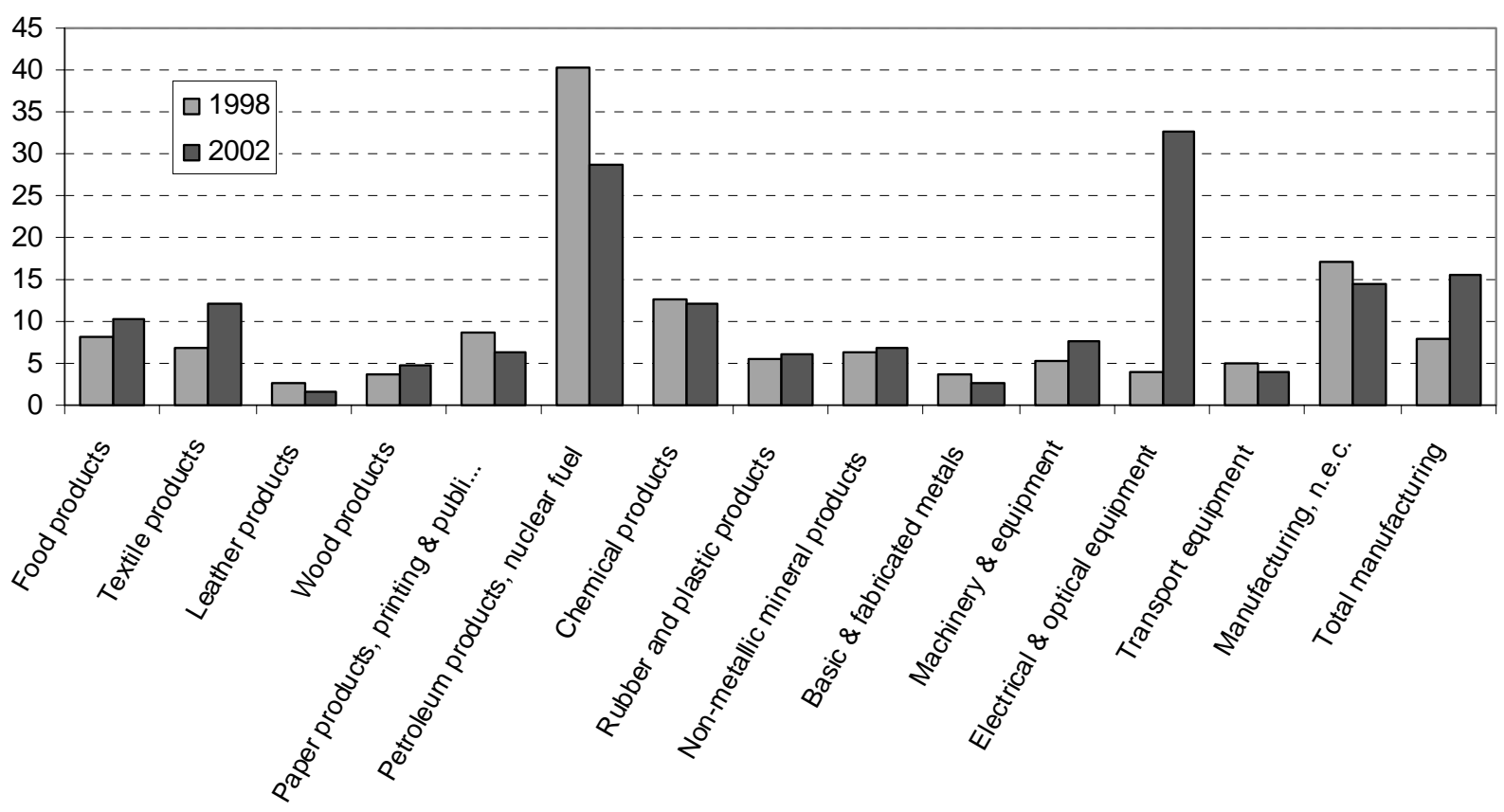

Source: Statistics Finland, see Annex 3.

\section{Results for Japan}

For Japan, a breakdown of sales by product can be derived from the Basic Survey of Business Structure and Activities (BSBSA), which is an annual survey at the enterprise level of firms over 50 employees. This survey shows that the share of services sales by manufacturing firms has declined over the past years, primarily to a lower share of wholesale and retail trade in total manufacturing turnover (Figure 18). The share of other services, including information services, has risen slightly over time, but remains at a very low level. 
Figure 18. Share of manufacturing turnover by activity/product, Japan, 1997-2001 (in \%)

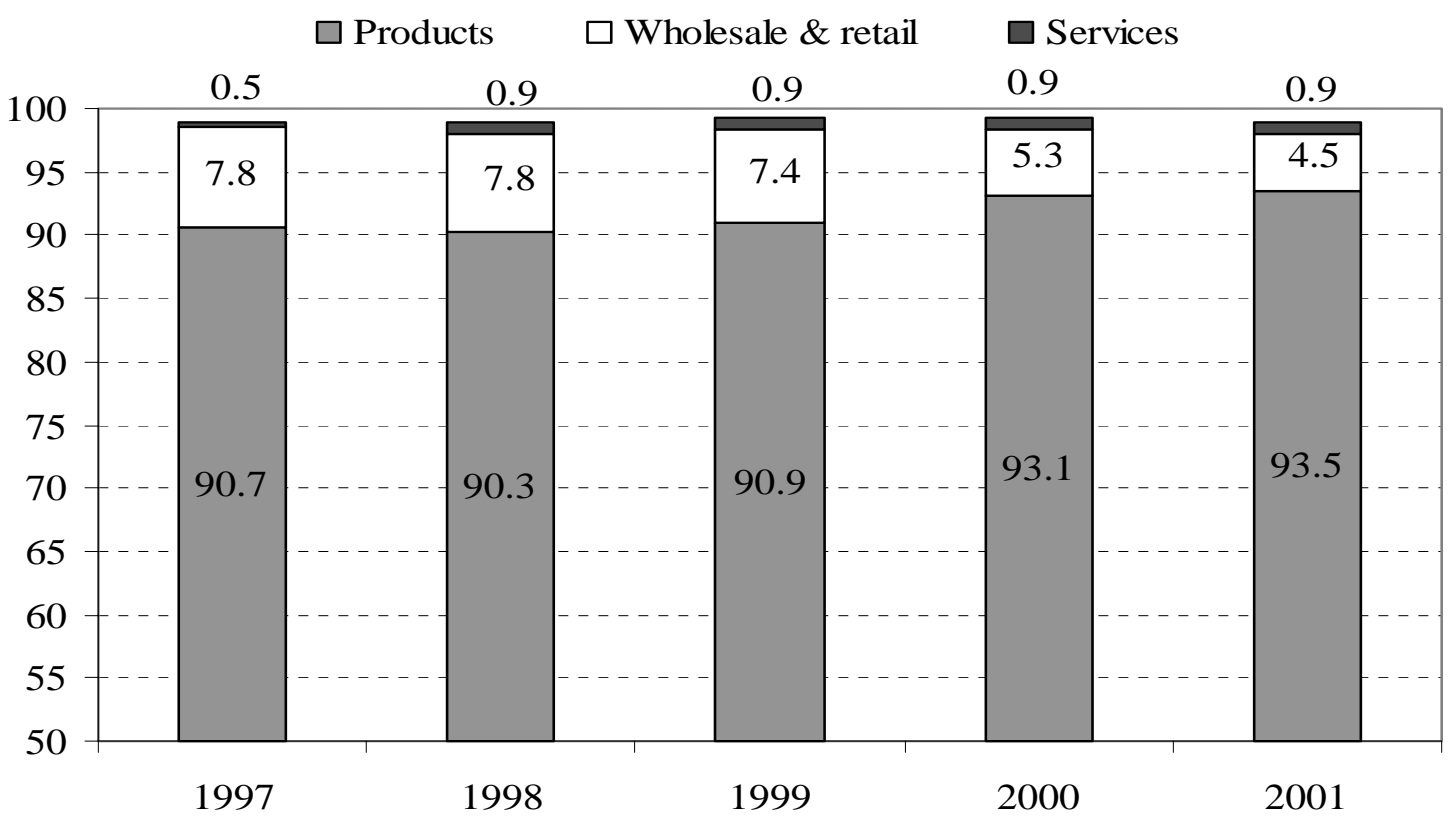

Source: Motohashi (2004).

\section{Results for New Zealand}

A breakdown of turnover was also provided by New Zealand, on the basis of its Annual Enterprise Survey. The data shown in Figure 19 refer to averages over the period 1999-2003, since these shares are quite volatile for some activities. In most manufacturing industries, income from services activities is below $10 \%$ of total sales. In some industries, notably printing and publishing (NACE D22), coke, petroleum products and nuclear fuel (NACE D23), basic metals (NACE D27), other transport equipment (NACE D35) and repair and retail sale of fuel (NACE G50), income from services activities is more substantial.

Figure 19. Share of income from services activities in total turnover in manufacturing and trade, New Zealand Average share over 1999-2003, \%

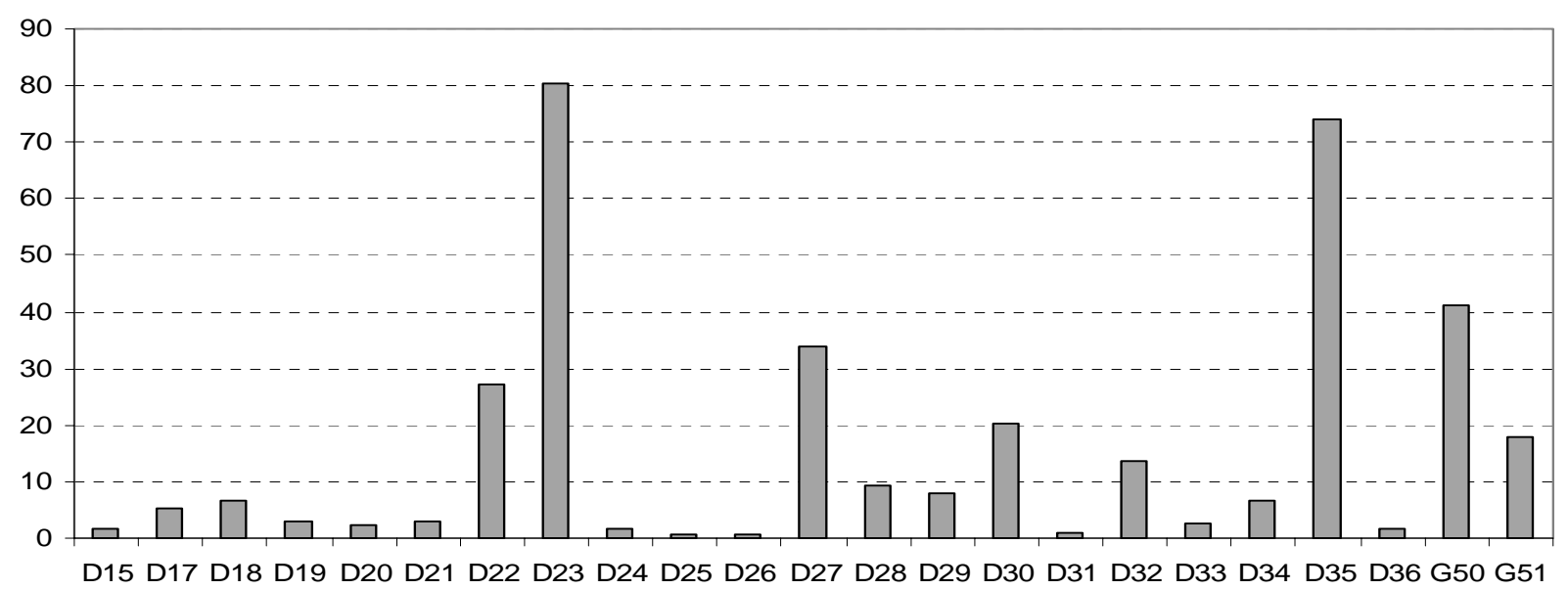

Note: The letters refer to NACE categories. 
Source: Statistics New Zealand.

\section{Results for Sweden}

Similar results can be derived for Sweden (Figure 20). These results point to a somewhat lower share of services activities in total turnover of the manufacturing sector than in Finland, rising from about $7.5 \%$ in 1997 to about $9.5 \%$ in 2002. The difference with the results for Finland may be linked to the statistical unit, which is a kind-of-activity unit (KAU) for Sweden and an enterprise unit for Finland (see Annexes 2 and 3). The strongest increases in the shares of services turnover can be found in leather products, machinery and equipment, and electrical and optical equipment. Changes in the underlying statistics may partly explain some of the changes shown in Figure 20 (see Annex 4).

Figure 20. Share of services turnover in mining and manufacturing industries, Sweden, 1997 and 2002 (in \%)

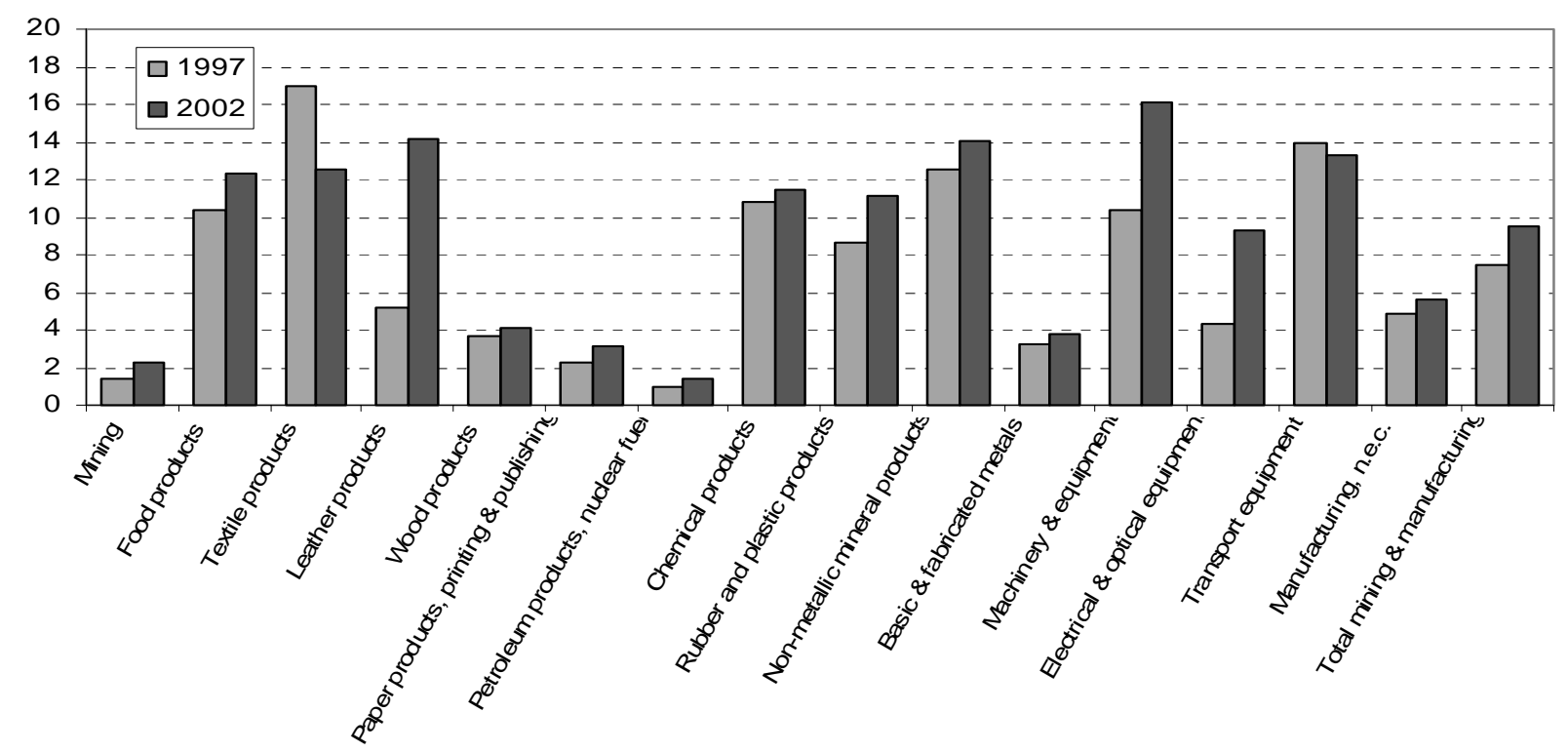

Source: Statistics Sweden, see Annex 4.

\subsection{Some conclusions from the micro work}

This section has presented evidence from six OECD countries regarding the composition of OECD economies on the basis of different statistical units. The following results emerge:

- In the European countries and New Zealand, there appears to be only a small difference between the composition of economies on the basis of data on enterprises and establishments. ${ }^{14}$ Moreover, the difference between the two statistical units appears to have declined over time, possibly because the variation in the core activities of establishments that make up an enterprise has diminished over time. In contrast, the Canadian data point to a considerable gap between the turnover (revenue) results based on enterprises and establishments. There are two possible interpretations for this result:

14. The difference between establishment and enterprise-level breakdowns also depends on the level of detail being considered; at a very detailed level, substantial differences may occur between the two measures. 
- Canadian enterprises are more diversified in their constituting establishments than enterprises in Europe or New Zealand.

- The Canadian enterprise unit may not be exactly the same as the European or New Zealand enterprise unit. One possibility is that the Canadian establishment unit is closer to the European and New Zealand enterprise unit than to the European establishment unit or the New Zealand kind-of-activity unit. Another possibility is that ancillary activity is treated differently between the regions.

- The largest differences between turnover shares based on enterprise data and establishment data is typically linked to wholesale activities that are carried out by manufacturing firms.

- Data on turnover by activity (product) for Finland, Japan, New Zealand and Sweden suggest that manufacturing firms derive part of their total turnover from secondary services activities, amounting to over $15 \%$ of total turnover in Finland to just below $10 \%$ in Japan and Sweden. In Finland, this is primarily the case in electrical and optical equipment where about $33 \%$ of total turnover in 2002 was due to services activities carried out within the manufacturing sector. In Sweden, the ratio has increased substantially in certain industries, including machinery and equipment and electrical and optical equipment.

These results suggest that in European countries, much of the diversity in manufacturing enterprises that emerges from anecdotal evidence is probably located at the level of the enterprise group, i.e. a combination of several individual enterprises. Some of these enterprises might be engaged in activities that are not the core activity of the enterprise group as a whole; for example, some European enterprise groups engaged in manufacturing might have separate enterprises for wholesale trade, transport or finance. At the same time, the results for Finland and Sweden suggest that manufacturing enterprises (in the Finnish case) and kind-of-activity units (in the Swedish case) draw a growing share of turnover from secondary services activities. In most cases, such turnover is not produced in separate statistical units (as the small difference between enterprise and establishment/KAU units suggests), but is due to secondary production of services activities in units primarily engaged in manufacturing production.

These results also raise a few issues that could be the subject of further work:

- It might be helpful to extend this work to some other OECD countries, notably larger European economies as well as other non-European countries.

- It is clearly important to consider whether the statistical terminology that is being used by countries is indeed comparable. The difference between the results for Canada, on the one hand, and the European countries, on the other hand, suggests that the concepts of enterprises and establishments are not necessarily the same on different sides of the Atlantic. The two main definitions that are currently being used are from ISIC and the EU. According to ISIC (ISIC, Rev 3.1, paragraphs 54-55), an enterprise has "autonomy in respect of financial and investment decision-making, as well as authority and responsibility for allocating resources for the production of goods and services. It may be engaged in one or many productive activities. The enterprise is the level at which financial and balance sheet accounts are maintained and from which international transactions, and international investment position (when applicable) and the consolidated financial position can be derived." The EU definition of an enterprise is the following (Council Regulation (EEC) No 696/93 of 15 March 1993): "The enterprise is the smallest combination of legal units that is an organisational unit producing goods or services, which benefits from a certain degree of autonomy in decision-making, especially for the allocation of its current resources. An enterprise carries out one or more activities at one or more 
locations." The main difference between these two definitions is that a group of enterprises is not an enterprise according to the EU definition, while it is an enterprise according to the ISIC definition. Further investigation of definitions might thus prove helpful.

- It is also important to consider to which extent the findings in this paper affect the calculation and interpretation of standard measures of economic structure. Such measures, e.g. share of different activities in value added and employment, are often based on the national accounts. These, in turn, often primarily allocate value added and employment on the basis of establishment data. This seems appropriate, since establishment data seem less affected by the blurring of services and manufacturing than enterprise data or data from other statistical units. At the same time, it remains important to account for secondary activity that is carried out at the level of the establishment, such as wholesale activity.

\section{Summary and conclusions}

The evidence presented in this paper demonstrates that the distinction between manufacturing and services is blurring. Moreover, interactions between services and manufacturing now take on many forms. The main results from the cross-country data can be summarised as follows:

1. Input-output tables demonstrate that services make important contributions to production, both through their direct contribution to total output and final demand, as well as through their indirect contribution through deliveries of intermediate inputs. The amount of services sector value added that is embodied in manufacturing goods has slowly risen over time and accounted for up to $25-30 \%$ of total output in some countries in the mid-1990s.

2. A growing share of workers in the manufacturing sector is engaged in services-related occupations. In some OECD countries, such as the Netherlands, more than 50\% of manufacturing workers were engaged in services-related occupations in 2002.

3. Despite anecdotal evidence of a growing share of services turnover within the manufacturing sector, firm-level evidence suggests that manufacturing enterprises in most countries are not very diversified, i.e. they do not have many separate establishments that are engaged in services production. Canada is a notable exception in this respect. In other countries, the diversification of manufacturing firms may primarily occur at the level of the enterprise group, i.e. enterprises in an enterprise group may be engaged in different activities.

4. At the same time, data on turnover by product suggest that manufacturing firms and establishments do derive a greater share of turnover from services activities, notably in countries such as Finland and Sweden. Most of these sales refer to wholesale and retail trade activities carried out by manufacturing firms.

The paper also suggests that while the distinction between manufacturing and services is becoming increasingly blurred, the two sectors still differ in their role in the economy. The services sector is more independent from other industries than the manufacturing sector. Most inputs that are necessary to produce demand for services derive from the services sector itself. Manufacturing industries interact much more strongly with other industries, both as providers and as users of intermediate inputs. Even though services now contribute as providers of intermediate input to the performance of other industries, their role remains more limited than that of the manufacturing sector. 
The evidence presented in the paper also shows that both services and manufacturing are changing; the manufacturing sector is taking on characteristics of the services sector, with a growing share of services occupations and more revenues being derived from services, whereas services are becoming more like manufacturing as they have growing impacts on other sectors of the economy.

The paper also highlights the difficulties that exist in measuring emerging phenomena such as the interaction between manufacturing and services. By combining evidence from a variety of sources, the paper has attempted to build a picture of this interaction. However, several pieces of the puzzle are missing. For example, the micro evidence reported in section 6 of the paper should ideally be complemented by an analysis of turnover and employment at the level of the enterprise group. Moreover, the analysis on this issue currently only covers a limited number of OECD countries.

Finally, it will be necessary to consider how the material presented in this paper affects our current understanding of the driving forces in the manufacturing sector and the changes in business models that are occurring. This work is currently underway at the OECD and will be reported in a follow-up paper on the Changing Nature of OECD Manufacturing. 


\section{REFERENCES}

Ahmad, N., F. Lequillier, P. Marianna, D. Pilat, P. Schreyer, A. Wölfl (2003), "Comparing growth and labour productivity in the OECD area - the role of measurement", STI Working Paper 2003/14, OECD, Paris.

Antràs, P., E. Helpman (2003), Global Sourcing, NBER Working Paper, 10082.

Arnoldus, P. (2003), "Op weg naar de diensteneconomie", CPB Memorandum No. 83, CPB Netherlands Bureau of Economic Policy Analysis, The Hague.

Camus, B. (2004), "The diversification of services companies in France", paper presented to OECD workshop on services, INSEE, mimeo.

Czarnitzki, D., A. Spielkamp (2000), "Business Services in Germany: Bridges for Innovation", ZEW-Diskussion Papers, No. 00-52.

Dathe, D., G. Schmid (2000), "Determinants of Business and Personal Services: Evidence from West-German Regions", WZB-Discussion Paper, FS I 00 - 202, Berlin.

Falk, M., Koebel, B.M. (2002), Outsourcing, Imports and Labour Demand, Scandinavian Journal of Economics 104(4), 567-586.

Feenstra, R.C., G.H. Hanson (1999), The Impact of Outsourcing and High-Technology Capital on Wages: Estimates for the United States, 1979-1990, The Quarterly Journal of Economics, August 1999.

Fixler, D.J. and D. Siegel (1999), "Outsourcing and Productivity Growth in Services", Structural Change and Economic Dynamics, 10 (1999), 177-194.

Fontagné, L., M. Freudenberg (2001), "Intra-Industry Trade: Methodological Issue Reconsidered”, CEPII, Working Paper, No. 97-01.

Görzig, B.; A. Stephan (2002), "Outsourcing and Firm-level Performance”, DIW-Discussion Papers, 309, Berlin.

Grossman, G., E. Helpman (2003), "Outsourcing versus FDI in Industry Equilibrium", Journal of the European Economic Association, April-May 2003, 1(2) 317-327.

Heshmati, A. (2003), "Productivity Growth, Efficiency and Outsourcing in Manufacturing and Services", Journal of Economic Surveys, Vol. 17, No.1.

Kierkegaard, J.F. (2004), “Outsourcing - Stains on White Collar”, Institute for International Economics.

Kleinert, J. (2003), "Growing Trade in Intermediate Goods: Outsourcing, Global Sourcing, or Increasing Importance of MNE Networks?", Review of International Economics, 11(3), 464-482. 
Motohashi, K. (2004), "Statistical Analysis of the Internal Services Activities in Machinery Industry", Research Institute for Economy, Trade and Industry, mimeo (in Japanese).

Ochel, W., P. Schreyer (1990), "Beschäftigungsentwicklung im Bereich der privaten Dienstleistungen USA-Bundesrepublik Deutschland im Vergleich", Schriftenreihe des Ifo-Instituts für Wirtschaftsforschung, Nr. 123.

OECD (2005), "Potential Offshoring of ICT-Intensive Using Occupations", OECD, Paris, mimeo.

Stille, F. (2002), Output and Labor Productivity in Services Industries: problems of measurement and international comparison, Research notes, DIW, Berlin.

Wölfl, A. (2003), "Productivity growth in service industries - an assessment of recent patterns and the role of measurement", STI Working Paper 2003/7, OECD, Paris.

Wölfl, A. (2005), “The Service Economy in OECD Countries”, STI Working Paper 2005/3, OECD, Paris. 


\section{ANNEX 1: EMPLOYMENT FLOW MATRICES}

Table A1. Computed Employment-Flow Matrices

Employment in thousands

\begin{tabular}{|c|c|c|c|c|c|c|c|}
\hline \multirow[t]{3}{*}{ Canada } & & \multicolumn{6}{|c|}{.. to produce final demand in .. } \\
\hline & & \multicolumn{4}{|c|}{ Indirect } & \multirow[t]{2}{*}{ Direct } & \multirow[t]{2}{*}{ Total } \\
\hline & oyment of .. & $\begin{array}{c}\text { Manu- } \\
\text { facturing }\end{array}$ & Services & $\begin{array}{c}\text { Other } \\
\text { Industries }\end{array}$ & Total & & \\
\hline \multirow[t]{4}{*}{ Indirect } & Manufacturing & 543 & 458 & 313 & 1314 & 594 & 1908 \\
\hline & Services & 775 & 2596 & 663 & 4034 & 6748 & 10782 \\
\hline & Other Industries & 345 & 242 & 137 & 724 & 931 & 1655 \\
\hline & Total Indirect & 1663 & 3295 & 1113 & 6071 & & \\
\hline Direct & & 594 & 6748 & 931 & & 8273 & \\
\hline Total & & 2257 & 10043 & 2045 & & & 14344 \\
\hline
\end{tabular}

\begin{tabular}{|c|c|c|c|c|c|c|c|}
\hline \multirow[t]{3}{*}{ German } & & \multicolumn{6}{|c|}{.. to produce final demand in .. } \\
\hline & & \multicolumn{4}{|c|}{ Indirect } & \multirow[t]{2}{*}{ Direct } & \multirow[t]{2}{*}{ Total } \\
\hline & & $\begin{array}{c}\text { Manu- } \\
\text { facturing }\end{array}$ & Services & $\begin{array}{c}\text { Other } \\
\text { Industries }\end{array}$ & $\begin{array}{c}\text { Total } \\
\text { indirect }\end{array}$ & & \\
\hline \multicolumn{8}{|c|}{ Use of employment of .. } \\
\hline \multirow[t]{4}{*}{ Indirect } & Manufacturing & 4781 & 1396 & 859 & 7036 & 1398 & 8434 \\
\hline & Services & 2656 & 5379 & 1019 & 9054 & 17262 & 26316 \\
\hline & Other Industries & 1049 & 907 & -263 & 1693 & 3210 & 4904 \\
\hline & Total Indirect & 8486 & 7682 & 1615 & 17783 & & \\
\hline Direct & & 1398 & 17262 & 3210 & & 21870 & \\
\hline Total & & 9884 & 24944 & 4826 & & & 39653 \\
\hline
\end{tabular}

\begin{tabular}{|c|c|c|c|c|c|c|c|}
\hline \multirow[t]{3}{*}{ Japan } & & \multicolumn{6}{|c|}{.. to produce final demand in .. } \\
\hline & & \multicolumn{4}{|c|}{ Indirect } & \multirow[t]{2}{*}{ Direct } & \multirow[t]{2}{*}{ Total } \\
\hline & byment of .. & $\begin{array}{c}\text { Manu- } \\
\text { facturing }\end{array}$ & Services & $\begin{array}{l}\text { Other } \\
\text { Industries }\end{array}$ & $\begin{array}{c}\text { Total } \\
\text { indirect }\end{array}$ & & \\
\hline \multirow[t]{4}{*}{ Indirect } & Manufacturing & 4098 & 2305 & 2124 & 8526 & 5672 & 14199 \\
\hline & Services & 4318 & 6827 & 2420 & 13565 & 19479 & 33045 \\
\hline & Other Industries & 2777 & 1784 & 618 & 5179 & 6460 & 11639 \\
\hline & Total Indirect & 11193 & 10916 & 5162 & 27270 & & \\
\hline Direct & & 5672 & 19479 & 6460 & & 31612 & \\
\hline Total & & 16865 & 30395 & 11622 & & & 58882 \\
\hline
\end{tabular}

1. Canada, Japan, United States: 1997, Italy: 1992, Germany, France: 1995.

Source : OECD Input-Output tables. 
Table A1 cont'd. Computed Employment-Flow Matrices - continued Employment in thousands

\begin{tabular}{|c|c|c|c|c|c|c|c|}
\hline \multirow[t]{3}{*}{ France } & & \multicolumn{6}{|c|}{. to produce final demand in .. } \\
\hline & & \multicolumn{4}{|c|}{ Indirect } & \multirow[t]{2}{*}{ Direct } & \multirow[t]{2}{*}{ Total } \\
\hline & & $\begin{array}{l}\text { Manu- } \\
\text { facturing }\end{array}$ & Services & $\begin{array}{c}\text { Other } \\
\text { Industries }\end{array}$ & $\begin{array}{c}\text { Total } \\
\text { indirect }\end{array}$ & & \\
\hline \multicolumn{8}{|c|}{ Use of employment of .. } \\
\hline \multirow{4}{*}{ Indirect } & Manufacturing & 1263 & 858 & 375 & 2496 & 1716 & 4213 \\
\hline & Services & 1502 & 2722 & 641 & 4865 & 11570 & 16435 \\
\hline & Other Industries & 551 & 305 & 302 & 1158 & 1575 & 2733 \\
\hline & Total Indirect & 3315 & 3885 & 1318 & 8519 & & \\
\hline Direct & & 1716 & 11570 & 1575 & & 14862 & \\
\hline Total & & 5032 & 15456 & 2893 & & & 23381 \\
\hline
\end{tabular}

\begin{tabular}{|c|c|c|c|c|c|c|c|}
\hline \multirow[t]{3}{*}{ Italy } & & \multicolumn{6}{|c|}{.. to produce final demand in .. } \\
\hline & & \multicolumn{4}{|c|}{ Indirect } & \multirow[t]{2}{*}{ Direct } & \multirow[t]{2}{*}{ Total } \\
\hline & & $\begin{array}{l}\text { Manu- } \\
\text { facturing }\end{array}$ & Services & $\begin{array}{c}\text { Other } \\
\text { Industries }\end{array}$ & $\begin{array}{c}\text { Total } \\
\text { indirect }\end{array}$ & & \\
\hline \multicolumn{8}{|c|}{ Use of employment of .. } \\
\hline \multirow[t]{4}{*}{ Indirect } & Manufacturing & 1711 & 905 & 547 & 3163 & 2393 & 5556 \\
\hline & Services & 1384 & 2735 & 451 & 4570 & 9107 & 13676 \\
\hline & Other Industries & 933 & 526 & 335 & 1795 & 1621 & 3416 \\
\hline & Total Indirect & 4028 & 4167 & 1334 & 9528 & & \\
\hline Direct & & 2393 & 9107 & 1621 & & 13120 & \\
\hline Total & & 6420 & 13273 & 2955 & & & 22648 \\
\hline
\end{tabular}

\begin{tabular}{|c|c|c|c|c|c|c|c|}
\hline \multicolumn{2}{|c|}{ United States } & \multicolumn{6}{|c|}{.. to produce final demand in .. } \\
\hline & & \multicolumn{4}{|c|}{ Indirect } & \multirow[t]{2}{*}{ Direct } & \multirow[t]{2}{*}{ Total } \\
\hline & & $\begin{array}{l}\text { Manu- } \\
\text { facturing }\end{array}$ & Services & $\begin{array}{c}\text { Other } \\
\text { Industries }\end{array}$ & $\begin{array}{c}\text { Total } \\
\text { indirect }\end{array}$ & & \\
\hline \multicolumn{8}{|c|}{ Use of employment of .. } \\
\hline \multirow[t]{4}{*}{ Indirect } & Manufacturing & 7876 & 4094 & 2306 & 14276 & 4818 & 19095 \\
\hline & Services & 8237 & 27295 & 4247 & 39779 & 52277 & 92056 \\
\hline & Other Industries & 2831 & 3378 & -508 & 5701 & 11084 & 16785 \\
\hline & Total Indirect & 18944 & 34767 & 6046 & 59757 & & \\
\hline Direct & & 4818 & 52277 & 11084 & & 68179 & \\
\hline Total & & 23762 & 87044 & 17129 & & & 127936 \\
\hline
\end{tabular}

1. Canada, Japan, United States: 1997, Italy: 1992, Germany, France: 1995.

Source: OECD Input-Output tables. 


\title{
ANNEX 2: THE IMPACT OF CHOICE OF BUSINESS UNITS ON INDUSTRIAL COMPOSITION - THE CANADIAN EXPERIENCE
}

\author{
Desmond Beckstead \\ Micro-Economic Analysis Division, Statistics Canada
}

The relative importance of different sectors of an economy varies according to the business units of observation selected for measurement. Though most businesses are single-industry single-location operations, there are a relatively small number of firms that generate a significant level of economic activity, each operating across several industries and/or locations. In Canada, the Business Register (BR) - the file used as the frame for all surveys of economic production - supports four different levels of operations for each business; from the top down, they are:

- Enterprise - the most aggregate level of business unit; this entity is an economic transactor having the responsibility and the authority to allocate resources in the production of goods and services, thereby directing and managing the receipt and disposition of income, the accumulation of property, borrowing and lending, and maintaining complete financial statements accounting for these responsibilities.

- Company - an intermediate-level unit at which profit can be measured; often equivalent to a cost centre.

- Establishment - the lowest level within the business's hierarchy at which value added can be measured; this unit is the one most frequently used by surveys of economic production.

- Location - equivalent to each production unit in the business - defined as the lowest level unit in the hierarchy with dedicated capital, labour and a (production) process; in a manufacturing context, this unit is often called a plant.

The BR provides several size measures for all levels within the operational hierarchy. For the purposes of this exercise, we will limit the discussion to those that are readily available, and hence, most frequently used - employment and revenue. Concerning business units, companies are rarely surveyed directly, and so information on them is not regularly produced. Consequently, the remaining discussion will be limited to three varieties of units - enterprises, establishments and locations.

In the BR, the industrial classification assigned to each level of business unit is determined by the detailed industrial composition of the units immediately below it. Thus, for an enterprise, its industry is assigned based on the set of industries for the companies underneath it. Similarly, the industry of each establishment is determined by the industry mix of the locations linked to it. Currently each underlying industrial activity is weighted by its value added. This value added measure is estimated by the product of the industry's revenue and the ratio ${ }^{15}$ of value added to revenue for the sector of that industry. The dominant industry for each level is based on the industry with the largest share of value added.

15 These value added to revenue ratios are based on data from the Input-Output tables. 
Table 1. Share of Economic Activity by Sector for various choices of Business Unit

\section{NAICS Sector}

11 - Agriculture, Forestry, Fishing and Hunting 21 - Mining and Oil and Gas Extraction

22 - Utilities

23 - Construction

31-33 Manufacturing

41 - Wholesale Trade

44-45 Retail Trade

48-49 Transportations and

Warehousing

51 - Information and Cultural Industries

52 - Finance and Insurance

53 - Real Estate and Rental and Leasing

54 - Professional, Scientific and Technical Services

55 - Management of

Companies and Enterprises

56 - Administrative and

Support, Waste Management and Remediation Services

61 - Education Services

62 - Health Care and Social

Assistance

71 - Arts, Entertainment and

Recreation

72 - Accommodation and

Food Services

81 - Other Services (except

Public Administration)

91 - Public Administration

Total

Goods

Services
Employment shares Location Establishment Enterprise

\begin{tabular}{|c|c|c|}
\hline $1.97 \%$ & $1.96 \%$ & $1.84 \%$ \\
\hline $1.05 \%$ & $1.10 \%$ & $1.16 \%$ \\
\hline $0.66 \%$ & $0.75 \%$ & $0.85 \%$ \\
\hline $6.09 \%$ & $6.07 \%$ & $5.84 \%$ \\
\hline $12.41 \%$ & $12.83 \%$ & $14.09 \%$ \\
\hline $5.44 \%$ & $5.44 \%$ & $5.12 \%$ \\
\hline $10.76 \%$ & $10.96 \%$ & $11.16 \%$ \\
\hline $4.23 \%$ & $4.22 \%$ & $3.85 \%$ \\
\hline $2.09 \%$ & $2.15 \%$ & $2.26 \%$ \\
\hline $4.37 \%$ & $4.54 \%$ & $4.97 \%$ \\
\hline $2.43 \%$ & $2.44 \%$ & $2.36 \%$ \\
\hline $6.03 \%$ & $5.99 \%$ & $5.73 \%$ \\
\hline $2.63 \%$ & $1.66 \%$ & $1.62 \%$ \\
\hline $4.05 \%$ & $4.06 \%$ & $3.88 \%$ \\
\hline $7.22 \%$ & $7.20 \%$ & $6.92 \%$ \\
\hline $9.24 \%$ & $9.30 \%$ & $9.03 \%$ \\
\hline $1.71 \%$ & $1.72 \%$ & $1.65 \%$ \\
\hline $7.72 \%$ & $7.74 \%$ & $7.57 \%$ \\
\hline $3.90 \%$ & $3.89 \%$ & $3.70 \%$ \\
\hline $5.98 \%$ & $5.96 \%$ & $6.38 \%$ \\
\hline $100.00 \%$ & $100.00 \%$ & $100.00 \%$ \\
\hline $22.19 \%$ & $22.72 \%$ & $23.78 \%$ \\
\hline $77.81 \%$ & $77.28 \%$ & $76.22 \%$ \\
\hline
\end{tabular}

Revenue shares Location Establishment Enterprise

\begin{tabular}{|c|c|c|}
\hline $1.62 \%$ & $1.61 \%$ & $1.16 \%$ \\
\hline $2.76 \%$ & $2.75 \%$ & $4.95 \%$ \\
\hline $2.37 \%$ & $2.41 \%$ & $1.93 \%$ \\
\hline $4.59 \%$ & $4.57 \%$ & $3.71 \%$ \\
\hline $16.99 \%$ & $16.97 \%$ & $23.51 \%$ \\
\hline $15.00 \%$ & $14.99 \%$ & $9.17 \%$ \\
\hline $9.68 \%$ & $9.70 \%$ & $9.22 \%$ \\
\hline $3.14 \%$ & $3.19 \%$ & $2.83 \%$ \\
\hline $1.96 \%$ & $1.95 \%$ & $2.05 \%$ \\
\hline $9.75 \%$ & $9.80 \%$ & $11.96 \%$ \\
\hline $2.01 \%$ & $2.00 \%$ & $2.37 \%$ \\
\hline $3.41 \%$ & $3.40 \%$ & $3.89 \%$ \\
\hline $1.93 \%$ & $1.92 \%$ & $1.37 \%$ \\
\hline $1.73 \%$ & $1.73 \%$ & $1.54 \%$ \\
\hline $3.00 \%$ & $3.00 \%$ & $2.44 \%$ \\
\hline $2.88 \%$ & $2.88 \%$ & $2.35 \%$ \\
\hline $0.85 \%$ & $0.84 \%$ & $0.68 \%$ \\
\hline $1.66 \%$ & $1.66 \%$ & $1.57 \%$ \\
\hline $1.87 \%$ & $1.87 \%$ & $1.91 \%$ \\
\hline $12.81 \%$ & $12.76 \%$ & $11.37 \%$ \\
\hline $100.00 \%$ & $100.00 \%$ & $100.00 \%$ \\
\hline $28.32 \%$ & $28.31 \%$ & $35.26 \%$ \\
\hline $71.68 \%$ & $71.69 \%$ & $64.74 \%$ \\
\hline
\end{tabular}

Using revenue and employment to measure economic activity, Table 1 provides the share of activity for each NAICS sector as the choice of business unit moves up the organizational structure from location through to enterprise. Using manufacturing as an example, between $12 \%$ and $13 \%$ of all employment occurs in the manufacturing sector when measured by the employment of locations and establishments in that sector. This share increases to $14 \%$ when measured by the employment of manufacturing enterprises. The share of revenue associated with manufacturing locations and establishments is a consistent $17 \%$, but the share of revenue associated with manufacturing enterprises is a much larger $231 / 2 \%$. 


\title{
ANNEX 3: METHODOLOGICAL DETAILS FOR FINLAND
}

\author{
By Satu Nurmi, Statistics Finland
}

Table A2.1: FINLAND, part 1: Breakdown of turnover and employment by enterprise and establishment

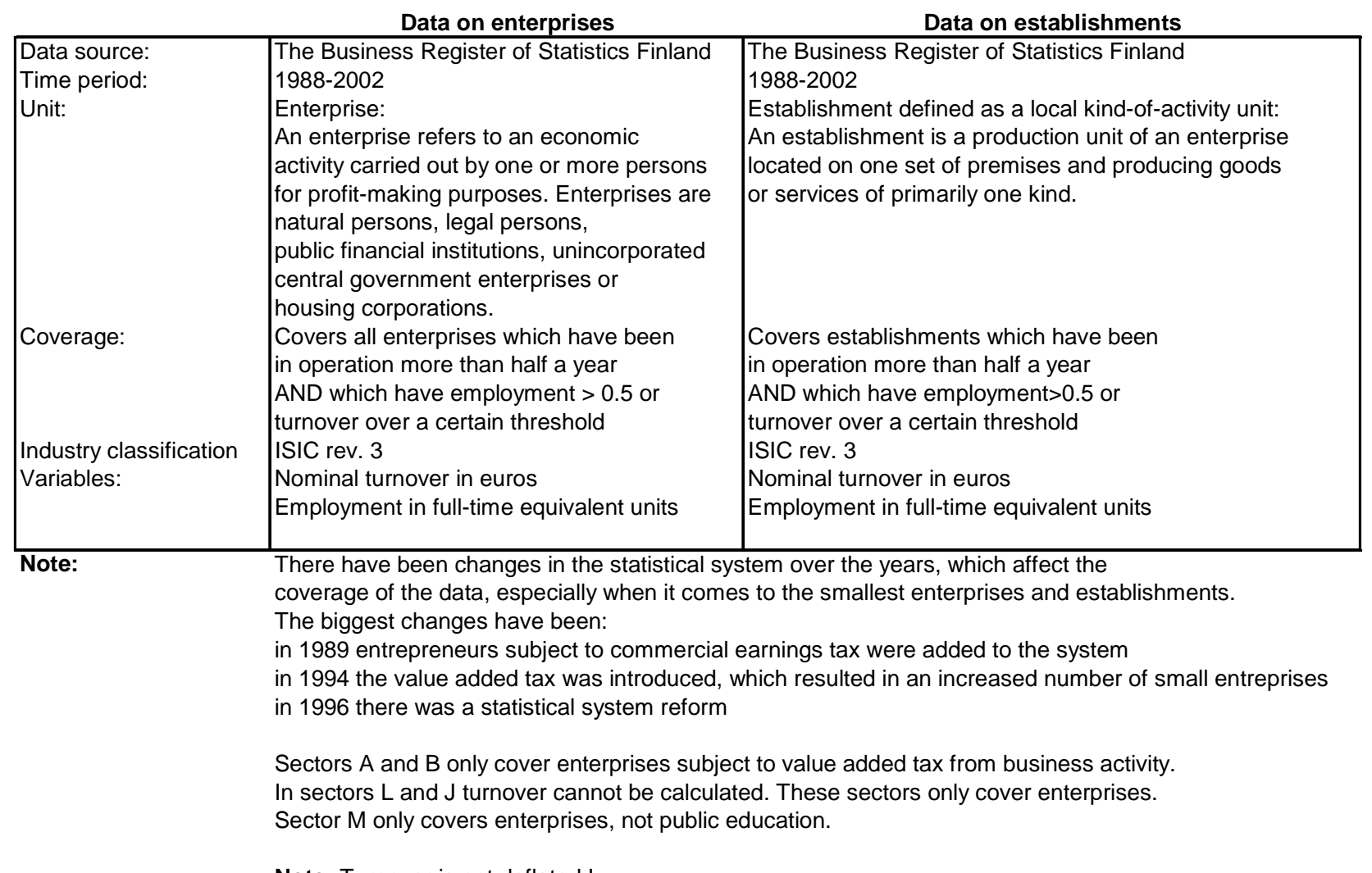

Note: Turnover is not deflated! 
Table A2.2: FINLAND, part 2: Turnover by activity

$\begin{array}{ll}\text { Data source: } & \text { Business Structures: Financial Statements Statistics, including information from the Business Register, } \\ & \text { Tax Administration's Business Taxation Data and direct enterprise inquiry } \\ \text { Time period: } & 1998-2002 \\ \text { Unit: } & \text { Enterprise defined as in the Business Register } \\ \text { Coverage: } & \text { Corresponds closely to the Business Register } \\ & \text { Turnover by activity is included only in the direct enterprise inquiry which includes only the large enterprises. } \\ & \text { The classification criterion for a large enterprise is the number of employees and the limit differs by economic } \\ & \text { activity (10, } 20 \text { or } 50 \text { persons). } \\ & \text { A sample from small construction and trade enterprises is also selected to the inquiry. For other enterprises, this } \\ & \text { information is imputed } \\ \text { Industry classification: } & \text { ISIC rev. } 3 \\ \text { Variables: } & \text { Turnover in Euros } \\ \text { Note: } & \text { Sectors A, B, J and L are excluded } \\ & \text { M only covers private enterprises }\end{array}$

Turnover from manufacturing activities (turnover_manuf) includes:

shipments of products

shipments of produced electricity

shipments of produced steam

network activity (energy sector)

industrial repair and set up shipments

wage work

\section{Turnover from services activities (turnover_serv) includes:}

commercial activity (sales of mercantile commodities including transmitted electricity)

agency activity

restaurant activity

hotel activity

other services activity

\section{Turnover from construction activities (turnover_constr) includes:}

construction of buildings

civil engineering

renting of construction or demolition equipment with operator

other construction activity (plumbing, painting etc.)

stock trading in construction

Turnover from other activities (turnover_other) includes:

turnover from agriculture and forestry

turnover from other activities

Note: Turnover may be negative due to e.g. corrections to previous year's turnover.

This shows up especially in the turnover from other activities. 


\title{
ANNEX 4: THE INTERACTION OF MANUFACTURING AND SERVICES - THE SWEDISH EXPERIENCE
}

\author{
Hans Björklund \\ Statistics Sweden
}

\section{Exercise 1}

\section{Method:}

- Source: The Swedish survey on Structural Business Statistics (SBS).

- Data for the enterprise level: Original data from SBS.

- Data for the local kind of activity unit level (LKAU): Data from SBS are broken down from the enterprise to the LKAU by using the number of employees per local unit from the business register.

- Statistical units: The enterprise in the Swedish statistical system is in many cases the same as one legal unit. Only fifty enterprises are combinations of legal units. The LKAU is, with very few exceptions, the same as a local unit.

\section{Results:}

If we use the local unit as the statistical unit instead of the enterprise, for the years 1999-2002, there seem to be small changes in the distribution among industries. This is the case for both turnover as well as employment. The share of employment for the service sector increases by at most $0.56 \%$. The share of turnover changes less than that, and even decreases for some years. There is, however, an exception for 2002 , where the service sector increases by $0.57 \%$. For the years $1997-1998$ there is a more significant shift between manufacturing and services. The shares for both turnover and employment rise with more than one per cent. The divergent results for 1997 and 1998 can probably be explained by ancillary activities. In 1999, the business register was revised and among other things updated with ancillary activities. This resulted in a correction of the activity code for units that earlier were classified with a primary activity code in services into an ancillary code connected to manufacturing.

\section{Exercise 2}

\section{Method:}

- Source: Original data from the Swedish Prodcom statistics.

- Statistical unit: The statistical unit in the Prodcom statistics is the Kind of activity unit (KAU) or part of a KAU.

- Comment 1: In the Swedish version of Prodcom statistics there is a request on service activities that is not obligatory according to the Prodcom regulation. This information is used in exercise 2.

- Comment 2: KAUs and in some cases parts of KAUs that have no production in NACE C-D are excluded from the survey. This means that the service production for the whole enterprise will certainly be underestimated. On the other hand, parts of enterprises outside ISIC 10-37 with substantial manufacturing production are included in the survey. This inclusion will probably lead to an overestimation of the share of service production. Another circumstance that can affect the results is that smaller enterprises are excluded from the survey. One could expect little service production in smaller enterprises, so it could give 
an overstatement of the shares of services. So there are factors both to overestimate and underestimate the share of services. What tendency is the strongest is hard to tell.

\section{Results:}

Exercise 2 shows that manufacturing enterprises have a rather large amount of service production. The share of the turnover has increased from $7.50 \%$ in 1997 to $9.47 \%$ in 2002 . This increase can however partly depend on the fact that the survey now includes more parts of the enterprise than in the earlier years. But one can not say that this explains the whole rise in service production within manufacturing enterprises, probably a rise has happened also in reality. The major service in manufacturing enterprises is not surprisingly trade. It is possible that the manufacturing enterprises engage in wholesale trade with commodities that supplement there own production. Other services are of less importance. One small comment: the figure for activity DC in 2002 is an outlier. DC is a very small activity in Sweden and the figure derives from an extraordinary action this year in just one enterprise.

\section{Conclusions:}

From exercise 2 we can see that manufacturing enterprises are to a rather large extent engaged in services activities. We can also observe that the major part of these service activities concerns trade. From exercise 1 we can draw the conclusion that these services are not carried out in special local units, at least not in any considerable amount. The service activities are rather carried out as a secondary activity in the local units within the enterprise. So from these exercises we can learn that it is important to see what happens within the manufacturing enterprises regarding services as a secondary activity, but that a splitting up into local units is of less value for that purpose. 